\title{
Investigation of 2-butoxyethanol as biodiesel additive on fuel property and combustion characteristics of two neat biodiesels
}

\author{
Kemal Masera1 ${ }^{1}$, Abul K. Hossain ${ }^{*}$, Philip A. Davies ${ }^{3}$, Khalid Doudin ${ }^{2}$ \\ ${ }^{1}$ Mechnaical Engineering and Design, ${ }^{2}$ Chemical Engineering and Applied Chemistry \\ School of Engineering and Applied Science, \\ Aston University, Birmingham B4 7ET, UK. \\ ${ }^{3}$ School of Engineering, University of Birmingham, Birmingham B15 2TT, UK. \\ *Corresponding author. E-mail address: a.k.hossain@aston.ac.uk (Abul K. Hossain).
}

\begin{abstract}
Neat biodiesels are not preferred for use in the compression ignition (CI) engines due to their high viscosities and related operational difficulties. This study investigated the fuel properties and combustion characteristics when 2-butoxyethanol additive was mixed separately with waste cooking oil biodiesel (W100) and rapeseed oil biodiesel (R100). Compared to neat biodiesels, the viscosities (at $40{ }^{\circ} \mathrm{C}$ ) of the $\mathrm{W} 100$ and R100 were reduced by $12.5 \%$ and $9.8 \%$ respectively, when they were blended separately with $15 \%$ 2-butoxyethanol. Four different samples such as W100, mixture of 85\% W100 and 15\% 2-Butoxyethanol (W85), R100, mixture of $85 \%$ R100 and 15\% 2-Butoxyethanol (R85) were tested in a multi-cylinder CI engine. The thermal efficiency of the W85 fuel was higher than fossil diesel by approximately $3.7 \%$. Total combustion duration of the biodiesel-additive blends were shorter than neat biodiesels and fossil diesel. Biodiesel-additive blends provided approximately $6 \%$ higher in-cylinder peak pressures. At full load, W85 fuel gave up to $5.4 \%$ reduced $\mathrm{NO}_{\mathrm{x}}$ emissions than neat biodiesel. The CO, HC and smoke emissions were decreased by up to $36 \%, 100 \%$ and $79 \%$ respectively. The study concluded that 2-butoxyethanol could effectively be used as biodiesel additive to improve fuel property; and to achieve better combustion and reduced pollution.
\end{abstract}

Keywords: biodiesel; CI engine; combustion; emission; fuel additive; performance.

\section{Table of contents}

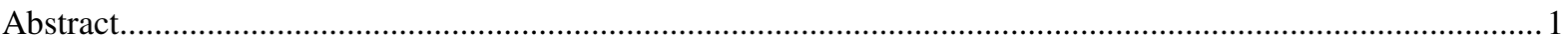

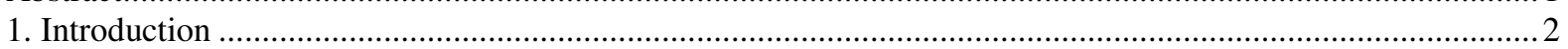

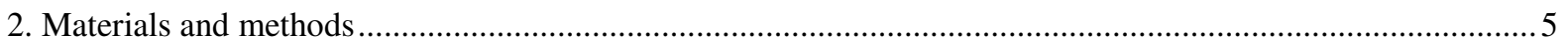

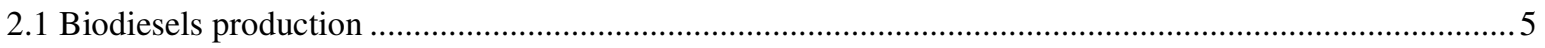

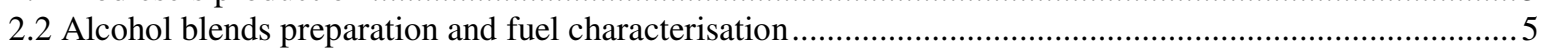

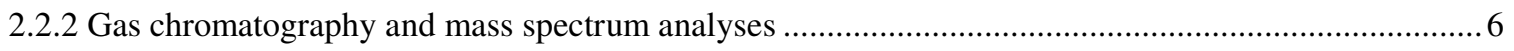

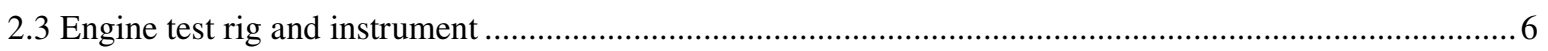

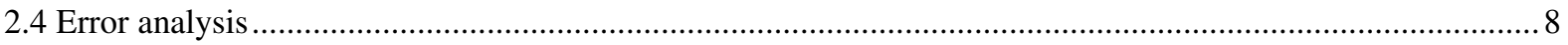

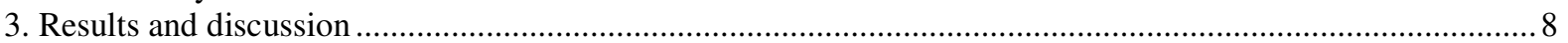

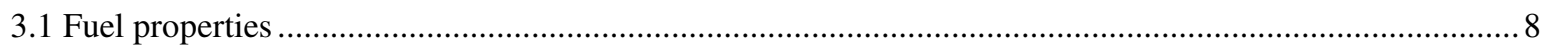

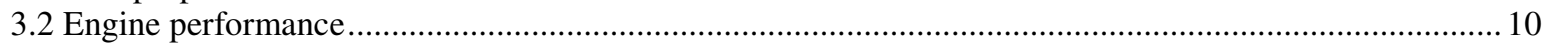

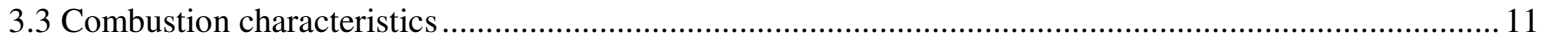

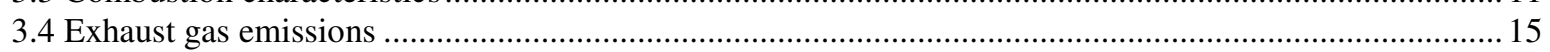

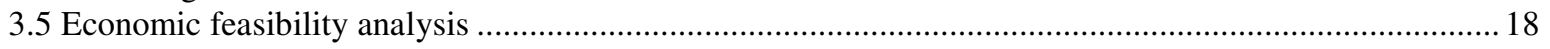

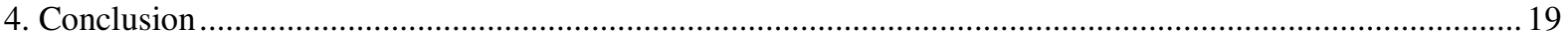

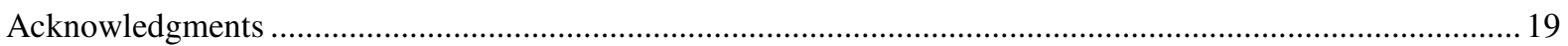

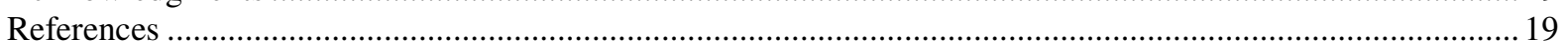


50 Abbreviations

After top dead centre

Brake specific fuel consumption

Before top dead centre

Brake thermal efficiency

Crank angle

Carbon, hydrogen and oxygen

Compression ignition

Diesel exhaust fluid

Diesel particulate filter

Exhaust gas recirculation

Fatty acid metyhyl ester

Fossil diesel

Gas chromatography and mass spectrum

Hydrotreated vegetable oil

Internal combustion

Potassium hydroxide

Lower heating value

Original equipment manufacturer

Polycyclic aromatic hydrocarbons

Polychlorinated debenzo-p-dioxins and dibenzofurans

Particulate matter

Rapeseed oil

Rapeseed oil biodiesel

Rapeseed oil biodiesel $85 \%$ by volume and 2 -Butoxyethanol $15 \%$ by volume

Selective catalytic reduction

Ultra low sulphur diesel

Waste cooking oil

Waste cooking oil biodiesel

Waste cooking oil biodiesel $85 \%$ by volume and 2 -Butoxyethanol $15 \%$ by volume

\section{Introduction}

Due to high thermal efficiency and low weight-to-power ratio diesel engines are still popular and widely used in many sectors. However, they consume huge quantities of fossil diesel fuel and emit harmful gas and soot emissions which cause damage to the human health and environment [1-3]. The carbon soot from diesel engine constitutes $73-83 \%$ of particulate matter (PM) [4]. The other pollutants in soot are: soluble organic fractions, ash content, trace metals, sulphur compounds, and other substances like polycyclic aromatic hydrocarbons (PAHs) [4,5]. Furthermore, polychlorinated debenzo-p-dioxins and dibenzofurans (PCDD/Fs) are reported as pollutant gas emissions from diesel engine [6,7]. The risk of respiratory, cardiovascular and lung cancer diseases are enhanced when a human is exposed to PM emission. Selective catalytic reduction (SCR) and diesel particulate filter (DPF) components are normally used to reduce the tail pipe NOx and Particulate Matter (PM) emissions respectively [8-10]. Other techniques such as exhaust gas recirculation (EGR), dual fuelling, water injection and retardation of injection timing are also used to reduce the NOx emission. However, adoption of these techniques requires modifications on the engine component; hence, their applications are limited due to the additional efforts and expenses involved.

Renewable alternative fuels could potentially be used in the internal combustion (IC) engines to replace fossil based fuels and to reduce harmful gas emissions [11,12]. Biodiesels are considered as one of the most promising alternative to fossil diesel due to better physico-chemical properties and life-cycle emission mitigation potential $[13,14]$. Literature reported that in China, replacing petroleum diesel with waste cooking oil biodiesel would decrease life cycle greenhouse gas emissions by up to $5.5 \times 10^{6}$ tons of $\mathrm{CO}_{2}$ equivalent [15]. Although, literature agreed that biodiesel fuel significantly reduced the $\mathrm{PM}, \mathrm{HC}, \mathrm{CO}$ and $\mathrm{CO}_{2}$ emissions, most researchers reported that the use of $100 \%$ biodiesel fuels (B100) in the unmodified diesel engines gave higher NOx emissions than 
those obtained for pure fossil diesel [16,17]. This phenomenon is also known as 'biodiesel NOx penalty' in the literature [18]. Other technical issues associated with the neat biodiesel (B100) use are: (i) starting the engine in cold weather, (ii) flow of biodiesel to injector due to higher viscosity, (iii) sticking and clogging of fuel injector holes, fuel filters, and inlet/exhaust vales, and (iv) compatibility of fuel supply pipe materials with the biodiesel [19-21]. To address these problems, Silva et al. investigated the effects of various alcohols used in transesterification (biodiesel production) process on the fuel properties of Macauba oil biodiesel [22]. They found that ethyl ester gave better cold filter plugging point property than methyl or isobutyl esters [22]. Another approach is to blend biodiesel with another fuel. Literature reported that blending biodiesel with fossil fuels or alcohols (and/or other additives) improved engine performance and reduced emissions [16,23]. Furthermore, researchers found that blending neat biodiesel with additives gave lower NOx and PM emissions than neat biodiesel (B100) operation [24,25]. The most common alcohols used as biodiesel additives are ethanol and methanol [26]. Datta and Mandal reported that blending palm stearin biodiesel with 15\% methanol (or ethanol) decreased the peak in-cylinder pressure with respect to the neat biodiesel [20]. They found that the $\mathrm{NO}_{\mathrm{x}}$ emissions were reduced by $19 \%$ and $30 \%$ due to methanol and ethanol addition respectively [20]. The smoke opacity was decreased dramatically when the biodiesel-alcohol blend was used [20]. In another study, the concentration of PM and PAHs emissions were investigated when 1-3\% acetone and 1\% isopropyl were added in the waste cooking oil biodiesel [4]. The authors reported that the use of both additives helped to reduce the $\mathrm{PAH}$ and PM emission by $24.1 \%$ and $53.2 \%$ respectively. Vedaraman et al. reported that $\mathrm{NO}_{\mathrm{x}}$ emissions were decreased when ethanol, methanol, diethyl ether and distilled water was added separately into fossil diesel-palm oil biodiesel blend [27]. Addition of methanol and water reduced the $\mathrm{NO}_{\mathrm{x}}$ emission by up to $2.7 \%$ and $7 \%$ respectively [27]. However, they found out that the $\mathrm{HC}$ emission was increased with the distilled water addition [27].

On the other hand, increase in the NOx emissions were also observed by the researchers when additives such as methanol, ethanol and butanol were added to neat biodiesel or diesel-biodiesel blends [28,29]. Yilmaz compared the effects of ethanol and methanol addition in diesel-biodiesel blends in a two cylinder direct injection type Kubota diesel generator set [28]. Blends containing 40\% biodiesel-40\% diesel-20\% alcohol and 45\% biodiesel$45 \%$ diesel-10\% alcohol, and neat fossil diesel were tested. The author reported that compared to fossil diesel, the brake specific fuel consumption (BSFC) of ethanol and methanol blends were increased by up to $28.6 \%$ and $58.3 \%$ respectively. The author found that the methanol blends did not help to decrease the $\mathrm{NO}_{\mathrm{x}}$ emissions. Whereas, ethanol blends reduced the $\mathrm{NO}_{\mathrm{x}}$ emissions by approximately $20 \%$ at mid-range loads [28]. Another study conducted by Tosun et al. investigated the influences adding ethanol, methanol and butanol separately into peanut oil biodiesel by testing these blends in a multi-cylinder direct injection type diesel engine [29]. They reported that $20 \%$ blends of methanol, ethanol and butanol with peanut oil biodiesel enhanced the engine torque output by about $1.2 \%, 3.4 \%$ and $6.1 \%$ respectively as compared to neat biodiesel operation. The $\mathrm{CO}$ emissions of methanol, ethanol and butanol blends were decreased by $4.8 \%, 1.8 \%$ and $9.1 \%$ respectively. They observed that the $\mathrm{NO}_{\mathrm{x}}$ emissions were increased by $13.8 \%, 4.1 \%$ and $17.4 \%$ for $20 \%$ blends of methanol, ethanol and butanol respectively [29]. Yasin et al. investigated the effects of 5\% methanol addition on B20 blend with diesel [25]. Methanol was mixed with the biodiesel-diesel blend using an ultrasonic agitator operated at $40 \mathrm{kHz}$ frequency. They found that the brake power for B20M5 fuel was decreased by approximately $7 \%$ and $10 \%$ than B20 and neat diesel fuels respectively. The BSCF of the engine was increased by about 4-6\% [25]. A reduction of approximately $17-18 \%$ in $\mathrm{CO}$ and $\mathrm{CO}_{2}$ emissions, and an increase of $13 \%$ in $\mathrm{NO}_{\mathrm{x}}$ emission was reported when the engine was fuelled with B20 M5 fuel [25]. In another study, Yilmaz investigated the effects of air intake temperature when the engine was fuelled with $85 \%$ biodiesel-15\% alcohol blends [26]. The author reported that the $\mathrm{CO}$ and $\mathrm{HC}$ emissions were reduced by increasing the air intake temperatures and with the increasing percentage of alcohol additives [26]. Sarikoc et al. tested butanol additive at 5\% and $10 \%$ blend ratios with $80 \%$ diesel - $20 \%$ waste cooking oil biodiesel blend [30]. They reported that the $\mathrm{CO}, \mathrm{CO}_{2}$, smoke opacity and NOx emissions were reduced by approximately $21 \%, 11 \%, 19 \%$ and $3 \%$ with $10 \%$ butanol addition [30]. However, HC emission was increased by approximately $32 \%$ as a result of worsened combustion efficiency [30]. They also reported $16.17 \%$ reduction on thermal efficiency of the engine due to low LHV and cetane number of the butanol [30]. The effect of n-butanol additive was also investigated along with the engine modifications such as EGR, piston geometry, injection timing and injection pressure [31]. The authors found out that toroidal piston was most suitable for n-butanol/diesel blends than biodiesel and diesel [31]. Zhang et al. investigated the influence of n-butanol, n-octane and 2-ethylhexanol alcohols as biodiesel additive in a CI engine using a wave-shaped piston bowl geometry [32]. The alcohols were blended separately either with rapeseed biodiesel or hydrotreated vegetable oil (HVO) at different volume fractions [32]. They reported that 
the $\mathrm{CO}$ and soot emissions were reduced when compared to fossil diesel [32]. The NOx emission was increased, the least increase of NOx emission was found to be $10 \%$ than fossil diesel for $2 \mathrm{EH} 40 \mathrm{H} 60$ blend $(40 \% 2$ ethylhexanol and $60 \% \mathrm{HVO}$ ) at full load condition [32]. The 30\% n-butanol and 70\% HVO blend gave optimum engine performance when wave-shaped piston bowl geometry was used [32]. Radheshyam et al. assessed the impact of using 1-pentanol as fossil diesel additive at volume fractions of 5\%, 10\%, 20\%, 30\% and $40 \%$ [33]. They reported that compared to pure fossil diesel operation and at high loads, $40 \% 1$-pentanol blend gave $8 \%$ lower NOx emission; however, the $\mathrm{CO}$ and $\mathrm{HC}$ emissions were increased from $0.01 \%$ (vol.) to $0.04 \%$ (vol.), and from $2.5 \mathrm{ppm}$ to $11.5 \mathrm{ppm}$ [33].

The above studies demonstrated that in general, blending biodiesel with alcohols improved engine performance characteristics. However, in the case of emission characteristics, no specific conclusions could be reached on whether adding alcohol helped to decrease the harmful gas emissions or not. So far the effects of ethanol, methanol and butanol on biodiesel fuelled engine operation were found in the literature. In this study, a new oxygenated additive '2-Butoxyethanol' will be used to assess the performance and emission characteristics of the engine operated with biodiesel-butoxyethanol blends. The '2-butoxyethanol' is an ether compound with ethanol branch containing additional oxygen molecule (Table 1). It is not a naturally occurring compound but obtained via different techniques in the laboratory environment like ethoxilation and etherification of butanol [34,35] Additional oxygen content in 2-butoxyethanol would further help to combust the biodiesel fuels more efficiently. Furthermore, the flash point of the 2-butoxyethanol is close to fossil diesel and higher than other alcohols used previously by the researchers (Table 1). In addition, 2-butoxyethanol have better surfactant properties which may help to reduce the corrosion rate of a biodiesel fuel on various engine components [34]. Due to these promising fuel properties, investigation of the 2-butoxyethanol as a biodiesel additive will be carried out in this study. It is important to note that no such study was found in the literature. Two different biodiesels produced from waste cooking oil (WCO) and rapeseed oil (RO) will be used in this study. Biodiesels will be blended separately with 2-butoxyethanol. A 3-cylinder diesel engine will be used to test the fuels. $\mathrm{BOSCH}$ emission analyser and Kistler combustion analysis kit 'KiBox' will be used for measurements of emission gases and combustion parameters. The main objectives of the study are: (i) Production of waste cooking oil and rape seed oil biodiesels in the laboratory, (ii) Preparation of 2-Butoxyethanol - biodiesel blends and investigation of the fuel properties, (iii) To study the performance, combustion and emission characteristics of the multi-cylinder engine operated with 2-Butoxyethanol-biodiesel blends, and (iv) Comparison of the biodiesel-additive fuelled engine characteristics with neat biodiesels and neat fossil diesel operation. Physical and chemical properties of the biodiesels, biodiesel blends and fossil diesel fuel samples will be carried out according to international standards.

Table 1

Properties of common alcohols and 2-butoxyethanol.

Methanol [36] Ethanol [37] Butanol [38] 2-butoxyethanol [39,40]

Structure

Linear formula

Molecular weight $(\mathrm{g} / \mathrm{mol})$

Heat of vaporisation $\left(\mathrm{kJ} / \mathrm{mol}\right.$ at $\left.25^{\circ} \mathrm{C}\right)$

Miscibility with organic solvents

Kinematic viscosity (at $25^{\circ} \mathrm{C}, \mathrm{mm}^{2} / \mathrm{s}$ )

Density $\left(\mathrm{kg} / \mathrm{m}^{3}\right)$

Flash point $\left({ }^{\circ} \mathrm{C}\right)$

Boiling point $\left({ }^{\circ} \mathrm{C}\right)$

Melting point $\left({ }^{\circ} \mathrm{C}\right)$
$-\mathrm{OH}$<smiles>CCO</smiles><smiles>CCCCO</smiles><smiles>CCCCOCCO</smiles>

\begin{tabular}{c}
$\mathrm{CH}_{3} \mathrm{OH}$ \\
32.042 \\
37.34 \\
$\mathrm{Yes}$ \\
0.69 \\
792 \\
12 \\
64.7 \\
-98 \\
\hline
\end{tabular}

$\mathrm{CH}_{3}\left(\mathrm{CH}_{2}\right)_{3} \mathrm{OH}$
74.123
52.35
$\mathrm{Yes}$
3.14
810
29
117.6
-90

$\mathrm{CH}_{3}\left(\mathrm{CH}_{2}\right)_{3} \mathrm{OCH}_{2} \mathrm{CH}_{2} \mathrm{OH}$

118.176

56.59

Yes

3.15

900

62

171

$-75$ 


\section{Materials and methods}

\subsection{Biodiesels production}

Two biodiesels were produced in the laboratory using two different feedstock ie. waste cooking oil and rapeseed oil. Waste cooking oil was collected from a local restaurant in Birmingham and rapeseed oil was procured from a supermarket. The feedstock was first filtered using sock filter, and then transesterified using methanol and potassium hydroxide $(\mathrm{KOH})$ catalyst. Initially, feedstock was heated up to approximately $55^{\circ} \mathrm{C}$ temperature. Then a mixture of methanol and $\mathrm{KOH}$ was introduced into the heated feedstock. Methanol to oil ratio was 1:5 by volume. The amount of $\mathrm{KOH}$ required was calculated by titration method. The mixture was stirred mechanically for around 30 minutes and transferred into a separator funnel for phase separation. The mixture was kept in the lab undisturbed for 24 hours, after that glycerol was removed and pure biodiesels were collected. Finally, produced biodiesels were washed by spraying distilled water. The water was removed from the biodiesel by separation technique and the washing was repeated couple of times until a clear colour biodiesel was obtained. Figure 1 shows the reaction schematic of the transesterification process. One (1) mole of triglyceride (feedstock) reacted with three (3) moles of methanol in the presence of KOH catalyst. The product is a mixture of glycerol and fatty acid methyl esters.

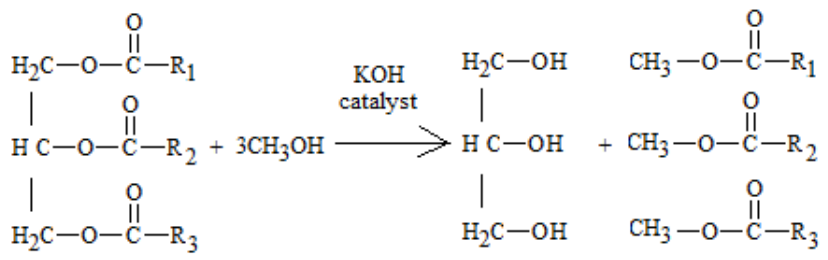

(Triglyceride) (Methanol) (Glycerol) (Fatty Acid Methyl Esters)

Fig. 1. Transesterification reaction mechanism

\subsection{Alcohol blends preparation and fuel characterisation}

\subsubsection{Additive mixing and characterisation}

2-Butoxyethanol (99\% purity) was purchased from Fisher Scientific (UK) and used as a biodiesel additive in the current study. The amount of additive added to biodiesel was 15\% (by volume); five different fuel samples were prepared: Ultra-low Sulphur Diesel (ULSD) as a reference fuel, neat waste cooking oil biodiesel (W100), blend of $85 \%$ waste cooking oil biodiesel and $15 \%$ of 2-butoxyethanol (W85), neat rapeseed oil biodiesel (R100), blend of $85 \%$ rapeseed oil biodiesel and $15 \%$ of 2-butoxyethanol (R85) (see Figure 2). The 2-butoxyethanol additive was miscible with biodiesels, no phase separation or solid formation was observed. Thus, no surfactant or mechanical stirring was needed. The reference ULSD diesel was purchased from Esso UK which satisfy the BS EN 590 specification [41]. The physical and chemical properties of the fuel samples were measured at the mechanical and chemical engineering laboratories of Aston University (Birmingham, UK). The calorific values were measured by bomb calorimeter (model Parr 6100) having an accuracy of $\pm 0.1 \%$. Kinematic viscosities were measured (according to ASTM D 445 and ISO 3105 standards) using the Cannon-Fenske viscometer (M100) and thermostatic water bath; the measurement uncertainty was $0.16 \%$. The density was measured by a hydrometer according to ASTM D7544 standard. Stanhope-Seta closed cup flash point tester (model: Setaflash 33000-0) was used to measure the flash point temperatures of the samples with the accuracy of \pm 0.5 .

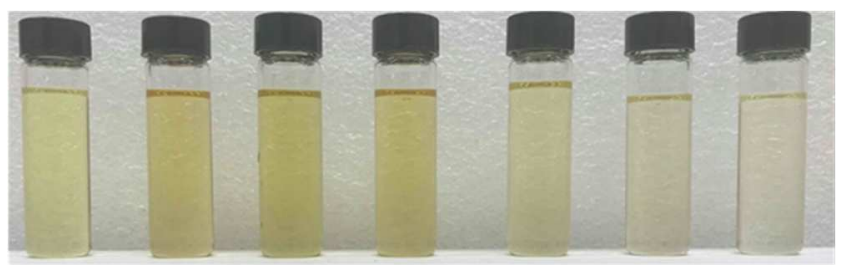

Fig. 2. Fuel samples from left to right: fossil diesel, WCO, W100, W85, rapeseed oil, R100 and R85 


\subsubsection{Gas chromatography and mass spectrum analyses}

The fatty acid methyl ester (FAME) contents of the biodiesel were determined by the gas chromatography Thermo Trace 1300 coupled with mass spectrometer (GCMS) equipment. Separation was performed on a capillary column Elite-5MS $(30 \mathrm{~m} \times 0.22 \mathrm{~mm}, 0.25 \mu \mathrm{m})$. The carrier gas was Helium with flow rate of 1.25 $\mathrm{mL} / \mathrm{min}$. The column temperature was programmed from 100 to $275{ }^{\circ} \mathrm{C}$ at the rate of $10^{\circ} \mathrm{C} / \mathrm{min}$. Fuel sample of $0.05 \mathrm{~g}$ was dissolved in $50 \mathrm{ml}$ of methanol, the mixture was then placed into ultrasonificator for 15 minutes. Then, $0.1 \mu \mathrm{L}$ of the prepared sample was transferred into test tube and loaded to the GCMS equipment. A split mode was used with the split ratio of $1: 10$. The temperature of the injector was set at $280{ }^{\circ} \mathrm{C}$. The mass spectrometer was set to scan in the range of 50-600 m/z with electron impact (EI) mode of ionization, the MS transfer line and the ion source temperatures were set at $250{ }^{\circ} \mathrm{C}$ and $200{ }^{\circ} \mathrm{C}$, respectively. The Carbon Hydrogen Oxygen ( $\mathrm{CHO}$ ) analysis, iodine value and cetane number of the fuels were estimated from the FAME composition found by GCMS analysis. Mass percentages/fractions of FAME components were multiplied by the relative values found in the literature (Table 2) to estimate the iodine value, cetane number and CHO content (equations 1 and 2).

${\text { Iodine } \text { Value }_{\text {Fuel }}=\sum(\text { Percent FAME }}_{i} \times$ Factor FAME $\left.E_{i}\right)$

Cetane Number Fuel $=\sum\left(\right.$ Fraction FAME $_{i} \times$ Cetane Number FAME $\left.E_{i}\right)$

\section{Table 2}

Fuel properties of individual FAME compounds.

\begin{tabular}{cccccccc}
\hline FAME & & $\begin{array}{c}\text { Iodine } \\
\text { value } \\
{[42]}\end{array}$ & $\begin{array}{c}\text { Cetane } \\
\text { number } \\
{[43]}\end{array}$ & $\begin{array}{c}\text { Cetane } \\
\text { number } \\
{[44]}\end{array}$ & $\begin{array}{c}\text { Carbon } \\
{[45]}\end{array}$ & $\begin{array}{c}\text { Hydrogen } \\
{[45]}\end{array}$ & $\begin{array}{c}\text { Oxygen } \\
{[45]}\end{array}$ \\
\hline Myristic & $\mathrm{C} 14: 0$ & 0 & 66.2 & 65.4 & 0.74 & 0.12 & 0.1322 \\
Palmitic & $\mathrm{C} 16: 0$ & 0 & 74.3 & 73.9 & 0.76 & 0.13 & 0.1185 \\
Palmitoleic & $\mathrm{C} 16: 1$ & 0.95 & 51 & 53.3 & 0.76 & 0.12 & 0.1194 \\
Stearic & $\mathrm{C} 18: 0$ & 0 & 75.6 & 82.3 & 0.77 & 0.13 & 0.1074 \\
Oleic & $\mathrm{C} 18: 1$ & 0.86 & 56.5 & 61.7 & 0.77 & 0.12 & 0.1081 \\
Linoleic & $\mathrm{C} 18: 2$ & 1.732 & 38.2 & 41.1 & 0.78 & 0.12 & 0.1088 \\
Linolenic & $\mathrm{C} 18: 3$ & 2.616 & 22.7 & 20.5 & 0.78 & 0.11 & 0.1096 \\
Arachidic & $\mathrm{C} 20: 0$ & 0 & 100 & 90.8 & 0.77 & 0.13 & 0.0982 \\
gadoleic & $\mathrm{C} 20: 1$ & 0.785 & 64.8 & 70.2 & 0.78 & 0.12 & 0.0988 \\
Behenic & $\mathrm{C} 22: 0$ & 0 & 100 & 100 & 0.78 & 0.13 & 0.0904 \\
Erucic & $\mathrm{C} 22: 1$ & 0.723 & 76 & 78.7 & 0.78 & 0.13 & 0.0909 \\
\hline
\end{tabular}

\subsection{Engine test rig and instrument}

In this research, three-cylinder Lister Petter compression ignition engine having an indirect injection system was used. Table 3 shows technical specification of the engine. The engine speed was kept constant at the rated speed of $1500 \mathrm{rpm}$ throughout the experiments. Approximately an hour engine tests were conducted to test each samples ie. W100, W85, R100, R85 and fossil diesel. Engine operating conditions such as air intake system, tail pipe configuration, lubricant, cooling agent, compression ratio, break mean effective pressure etc. were kept identical for each test. Engine performance, combustion and exhaust gas emission parameters were collected at six different engine loads: around $20 \%, 40 \%, 60 \%, 70 \%, 80 \%$, and $100 \%$. In order to get correct readings, the engine was allowed to run around 20 minutes between fuel changes. The tests procedures followed were: (i) the engine was first started with fossil diesel, (ii) then switched to neat biodiesel, and (iii) then switched to biodiesel-additive blend operation. In addition, the fuel supply system was flashed with the diesel by running the engine on diesel about 40 minutes before changing from WCO biodiesel fuels to RO biodiesel fuels. During the measurements, multiple readings were recorded in order to minimise possible errors and to ensure repeatability of the observed data. Figure 3 illustrates the experimental setup used in this study. The test engine was equipped with a dual fuel supply system which can be operated manually by a T-junction valve. At the end of the test, the 
engine was switched back to fossil diesel and operated for about 40 minutes to flush off the fuel supply and

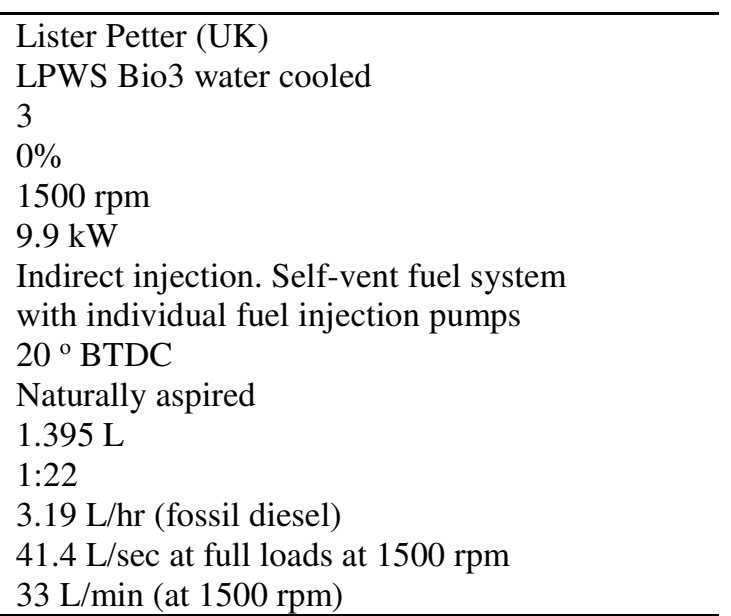

Table 3

Technical specification of the engine.

\begin{tabular}{ll}
\hline Manufacturer & Lister Petter (UK) \\
Model & LPWS Bio3 water cooled \\
Cylinder number & 3 \\
Exhaust gas recirculation & $0 \%$ \\
Rated speed & $1500 \mathrm{rpm}$ \\
Continuous power at rated speed & $9.9 \mathrm{~kW}$ \\
Fuel injection type & Indirect injection. Self-vent fuel system \\
& with individual fuel injection pumps \\
Fuel pump injection timing & $20^{\circ}$ BTDC \\
Aspiration & Naturally aspired \\
Cylinder capacity & $1.395 \mathrm{~L}$ \\
Compression ratio & $1: 22$ \\
Continuous power fuel consumption at $1500 \mathrm{rpm}$ & $3.19 \mathrm{~L} / \mathrm{hr}$ (fossil diesel) \\
Exhaust gas flow & $41.4 \mathrm{~L} / \mathrm{sec}$ at full loads at $1500 \mathrm{rpm}$ \\
Jacket water flow at full load & $33 \mathrm{~L} / \mathrm{min}$ (at $1500 \mathrm{rpm})$ \\
\hline
\end{tabular}
injection systems. An eddy current (Froude Hofmann AG80HS) dynamometer, with \pm 1 rpm speed and $\pm 0.4 \mathrm{Nm}$ torque accuracies was used. Fuel consumption of the engine was measured manually using a graduated cylinder on the fuel supply line. A commercial (Bosh BEA 850) five-gas emission analyser was used for measuring the tailpipe emissions. By this device, it was possible to measure the exhaust gases like $\mathrm{HC}, \mathrm{CO}, \mathrm{CO}_{2}, \mathrm{O}_{2}, \mathrm{NO}$ and excess air ratio (lambda). Furthermore, the smoke intensity of the exhaust gas was analysed through the Bosch RTM 430 smoke opacity measurement instrument. The combustion parameters of the test fuels were collected through pressure sensor installed inside the first cylinder (close to radiator) of the engine. Kistler $6125 \mathrm{C} 11$ pressure sensor with the Kistler 5064B11 charge amplifier was installed for the measurement of in-cylinder pressure. To log the fuel injection pressures, Kister 4065A500A0 pressure sensor along with the Kister 4618A0 amplifier was used. Crank angle was detected by using the Kister 2614A optical encoder. The Kister product, 2893AK8 model KiBox was installed to the system to log the data. The KiBoxCockpit software (supplied by Kistler) was connected to the KiBox hardware through an ethernet connection for monitoring and analysing the combustion parameters.

.




\subsection{Error analysis}

The error analysis is important for experimental studies. There are many factors that can cause uncertainties and errors in any experimental study such as environmental conditions, equipment selection and instrument calibration [33]. This error analysis helps to quantify the overall accuracy of the experimental investigation. Knowing the uncertainties of the exhaust gas analyser, dynamometer and the combustion analyser, specific uncertainties for BSFC, BTE, speed, load, time, crank angle, in-cylinder pressure and exhaust emissions were calculated by partial differentiation method (Table 4). This method was used for similar type of studies [33]. Specific uncertainties of the each parameter were calculated by minimum of 5 consecutive readings and overall uncertainty was calculated using equation 3.

$$
\text { Uncertainity }=\sqrt{\sum(\text { specific uncertainties })^{2}}= \pm 2.040 \%
$$

Table 4

The uncertainties of various parameters.

\begin{tabular}{lclc}
\hline Measurements & Uncertainty (\%) & Measurements & Uncertainty (\%) \\
\hline BSFC & 0.8 & $\mathrm{CO}_{2}$ & 0.1 \\
BTE & 0.8 & $\mathrm{O}_{2}$ & 0.1 \\
Speed & 0.2 & $\mathrm{HC}$ & 0.9 \\
Load & 0.2 & $\mathrm{CO}_{2}$ & 0.1 \\
Time & 0.8 & $\mathrm{NO}$ & 0.1 \\
Crank angle & 0.1 & smoke & 0.9 \\
Cylinder pressure & 0.7 & & \\
\hline
\end{tabular}

\section{Results and discussion}

In this section, fuel properties, engine performance, combustion characteristics, exhaust gas emissions and cost analysis of the test fuels are presented. The effects of 2-butoxyethanol additive on biodiesels are discussed, the results are compared with the corresponding results of the fossil diesel and neat biodiesels (W100 and R100).

\subsection{Fuel properties}

The FAME compositions of the biodiesels with and without 2-butoxyethanol additive are shown in Table 5. The major FAMEs found in this study were C16:0, C18:0, C18:1 and C18:2. Peaks for the mentioned FAMEs were clearly observed on the mass spectra and presented in Figure 4. According to GCMS results, for all biodiesels (including blends with 2-butoxyethanol), the first peaks were obtained at retention time of around 18 minutes which were representing the presence of the C16:0 (Figure $4 \mathrm{a}, \mathrm{b}, \mathrm{c}$ and $\mathrm{d}$ ). On the other hand, the following peaks between 21 and 22 minutes were accounted for $\mathrm{C} 18$ group FAMEs such as C18:0, C18:1 and C18:2. It was clearly observed that 2-butoxyethanol additive effected the mass fractions of the C18:1 and C18:2 FAMEs in the neat biodiesels by about 3\% in W100 and 6\% in R100. This phenomena directly influences the fuel properties especially cetane number and iodine value. According to BS EN 14214 standard for biodiesel, iodine value of biodiesel is directly proportional to FAME breakdown of the biodiesel [42]. Similarly, other fuel properties such as cetane number, lower heating value (LHV), density, cloud point etc. could also be predicted through FAME composition [44] (Table 2). 


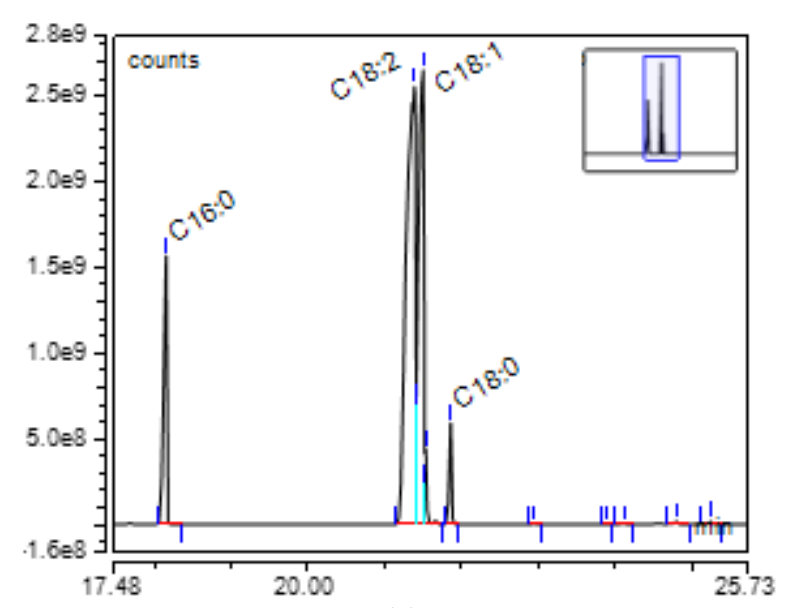

(a)

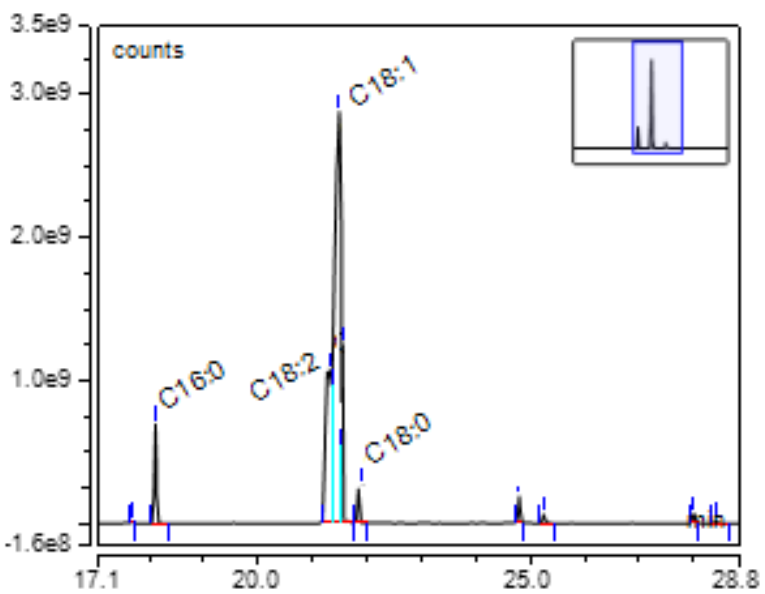

(c)

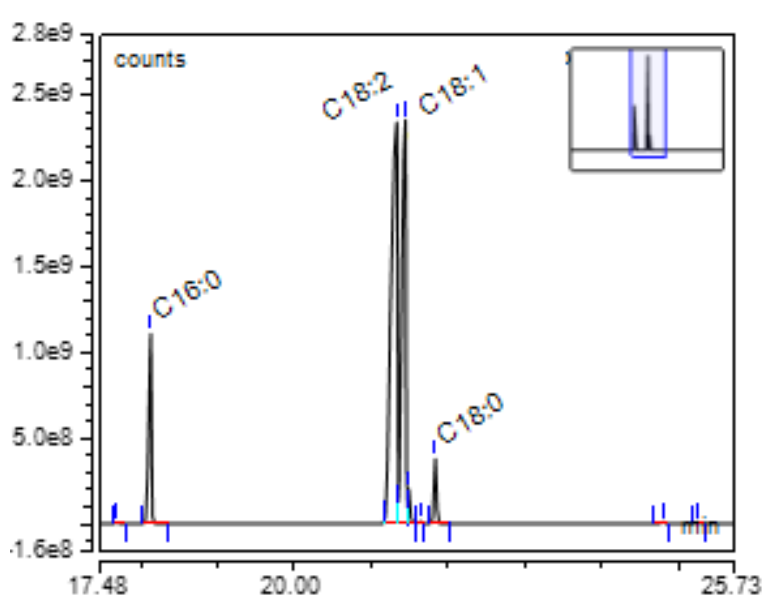

(b)

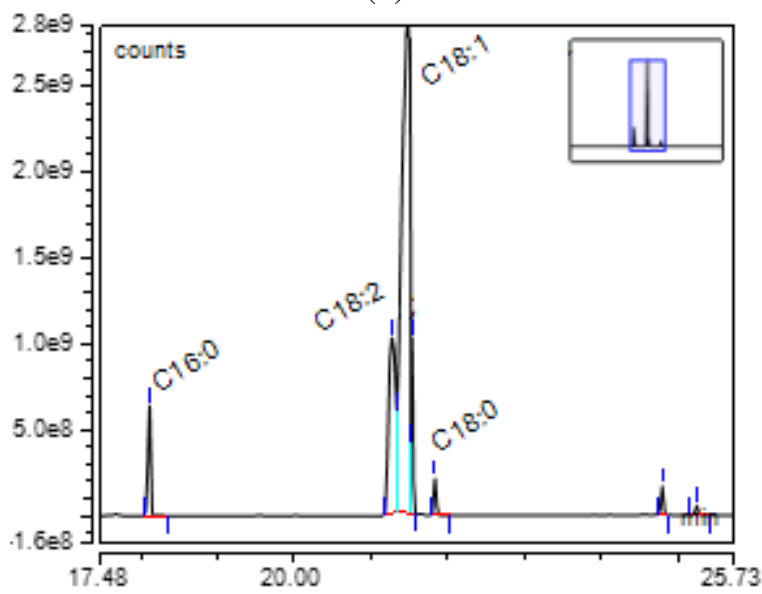

(d)

Fig. 4. Gas chromatography and mass spectrum analyse of (a) W100, (b) W85, (c) R100 and (d) R85.

Table 5

Mass percentages of the measured fatty acid methyl esters in biodiesels/blends.

\begin{tabular}{|c|c|c|c|c|c|c|}
\hline \multicolumn{3}{|c|}{ FAME } & \multicolumn{4}{|c|}{ Biodiesels/Blends } \\
\hline Formula & Fatty acid & Designation & W100 & W85 & R100 & $\mathrm{R} 85$ \\
\hline $\mathrm{C}_{17} \mathrm{H}_{34} \mathrm{O}_{2}$ & Palmitic & C16:0 & 10.4 & 10.1 & 4.1 & 4.3 \\
\hline $\mathrm{C}_{17} \mathrm{H}_{32} \mathrm{O}_{2}$ & Palmitoleic & C16:1 & 0.0 & 0.1 & 0.1 & 0.0 \\
\hline $\mathrm{C}_{19} \mathrm{H}_{38} \mathrm{O} 2_{2}$ & Stearic & C18:0 & 3.3 & 3.4 & 1.5 & 1.6 \\
\hline $\mathrm{C}_{19} \mathrm{H}_{36} \mathrm{O}_{2}$ & Oleic & C18:1 & 52.9 & 50 & 65.8 & 72.3 \\
\hline $\mathrm{C}_{19} \mathrm{H}_{34} \mathrm{O}_{2}$ & Linoleic & C18:2 & 32.8 & 36.0 & 26.0 & 19.2 \\
\hline $\mathrm{C}_{19} \mathrm{H}_{32} \mathrm{O}_{2}$ & Linolenic & C18:3 & 0.0 & 0.1 & 0.0 & 0.0 \\
\hline $\mathrm{C}_{21} \mathrm{H}_{42} \mathrm{O}_{2}$ & Arachidic & C20:0 & 0.2 & 0.0 & 0.5 & 0.5 \\
\hline $\mathrm{C}_{21} \mathrm{H}_{40} \mathrm{O}_{2}$ & gadoleic & C20:1 & 0.2 & 0.4 & 1.3 & 1.4 \\
\hline $\mathrm{C}_{23} \mathrm{H}_{46} \mathrm{O}_{2}$ & Behenic & $\mathrm{C} 22: 0$ & 0.2 & 0.0 & 0.2 & 0.2 \\
\hline $\mathrm{C}_{23} \mathrm{H}_{44} \mathrm{O}_{2}$ & Erucic & $\mathrm{C} 22: 1$ & 0.0 & 0.0 & 0.5 & 0.5 \\
\hline
\end{tabular}

Table 6 shows the fuel properties of the test fuels and the British biodiesel norms ie. BS EN 14 214. The kinematic viscosities (at $40^{\circ} \mathrm{C}$ ) of the $\mathrm{W} 100$ and R100 biodiesels were reduced by $12.5 \%$ and $9.8 \%$ respectively when $15 \%$ (by volume) 2-butoxyethanol additive was added to biodiesels. The densities of the W100 and R100 biodiesels did not change with the addition of the additive, as 2-butoxyethanol has similar density value like biodiesels (Table 1). However, the higher heating value (HHV) and flash point temperatures were negatively 
about $1 \%$ and $1.8 \%$ respectively. Similarly, the flash points of W85 and R85 were measured relatively low as 87 ${ }^{\circ} \mathrm{C}$ (decreased by about $49 \%$ than $\mathrm{W} 100$ ) and $81{ }^{\circ} \mathrm{C}$ (decreased by about $53 \%$ than $\mathrm{R} 100$ ). This requires more precautions for storage and transportation of the W85 and R85 fuels. Iodine value and degree of unsaturation were also slightly reduced due to the additive addition. Carbon, hydrogen and oxygen contents were not significantly affected by the 2-butoxyethanol additive (Table 6). The cetane number was slightly improved when 2-butoxyethanol was added to biodiesel (Table 6). Overall, fuel characterisation results proved that 2butoxyethanol (by 15\% volume) can be used as biodiesel additive to replace neat biodiesel or neat fossil diesel use in the compression ignition (CI) engine.

Table 6

Fuel properties of the test fuels and BS EN 14214 standard.

\begin{tabular}{|c|c|c|c|c|c|c|c|c|}
\hline Fuel Property & Unit & Method & Diesel & W100 & W85 & R100 & $\mathrm{R} 85$ & BS EN 14214 \\
\hline Kinematic Viscosity at $40^{\circ} \mathrm{C}$ & $\left(\mathrm{mm}^{2} / \mathrm{s}\right)$ & EN ISO 3104 & 2.78 & 5.05 & 4.42 & 4.6 & 4.15 & $3.5-5.0$ \\
\hline Density & $\left(\mathrm{kg} / \mathrm{m}^{3}\right)$ & EN ISO 3675 & 828 & 882 & 882 & 880 & 880 & $860-900$ \\
\hline LHV & $(\mathrm{MJ} / \mathrm{kg})$ & Theoretical & 41.99 & 35.71 & 35.34 & 36.46 & 35.81 & $\mathrm{n} / \mathrm{a}$ \\
\hline Flash point & $\left({ }^{0} \mathrm{C}\right)$ & EN ISO 3679 & 61.5 & 169 & 87 & 173 & 81 & $101 \mathrm{~min}$ \\
\hline Iodine value & (g iodine $/ 100 \mathrm{~g}$ ) & EN 14111 & $\mathrm{n} / \mathrm{a}$ & 120 & 118 & 103 & 97 & $120 \max$ \\
\hline Cetane number & $(-)$ & Calculated[43] & 54 & 49 & 50 & 53 & 55 & $51 \mathrm{~min}$ \\
\hline Degree of unsaturation & $(\% \mathrm{~m} / \mathrm{m})$ & Calculated[46] & $\mathrm{n} / \mathrm{a}$ & 2.39 & 2.37 & 2.20 & 2.13 & $\mathrm{n} / \mathrm{a}$ \\
\hline Carbon content & $(\% \mathrm{~m} / \mathrm{m})$ & Theoretical[45] & 86.6 & 77.14 & 77.13 & 77.12 & 77.08 & $\mathrm{n} / \mathrm{a}$ \\
\hline Hydrogen content & $(\% \mathrm{~m} / \mathrm{m})$ & Theoretical[45] & 13.4 & 11.91 & 11.93 & 12.04 & 12.08 & $\mathrm{n} / \mathrm{a}$ \\
\hline Oxygen content & $(\% \mathrm{~m} / \mathrm{m})$ & Theoretical[45] & 0.07 & 10.95 & 10.95 & 10.84 & 10.84 & $\mathrm{n} / \mathrm{a}$ \\
\hline
\end{tabular}

\subsection{Engine performance}

The biodiesel-additive blends gave higher BSFC than both neat biodiesels and fossil diesel (Figure 5). On average, BSFC of the W85 was $4.3 \%$ and $14.1 \%$ higher than W100 and diesel fuel respectively. Similarly, BSFC of the R85 was observed as $5.2 \%$ and $18.8 \%$ greater than R100 and diesel respectively. This increase on BSFC can be attributed to the reduced LHV of the blends (due to addition of additive) (Table 6). However, it was found out that the BSFC of the biodiesel blends were improved with the increase in engine load. At maximum load, the BSFC of the biodiesel blends were only $1 \%$ higher than neat biodiesels. This was mainly due to the higher enthalpy of vaporisation of the blends, which led to better combustion under higher engine loads (ie. temperatures) [26]. Both W85 and R85 fuels produced similar BSFC trends; however, BSFC of W85 fuel was slightly (0-3\%) lower than that of R85 fuel (Figure 5). Figure 6 shows the relationship between the brake Thermal Efficiency (BTE) and engine load for all test fuels. Compared to neat biodiesels, the BTE of the engine was observed 3-6\% lower for W85 and R85 fuels. However, the results showed that of all the test fuels, W100 and W85 fuels gave highest BTE. The BTE of the W100 and W85 fuels were approximately 5\% and 3\% higher than the corresponding fossil diesel values. The improved BTE's can be explained by the higher oxygen content of the biodiesels which in turn enhances the combustion [47,48]. Despite the fact that the HHV of W100 and W85 were lower than fossil diesel, the presence of fuel borne oxygen content improved the diffusion combustion, which resulted higher BTE [49]. On the other hand, R85 fuel provided slightly lower BTE than the fossil diesel. The BTE of the R100 fuel was around 4\% lower than that of W100. These differences in BTE values between two different biodiesels could be attributed to their fuel properties such as oxygen content, density and iodine value (Table 6). 


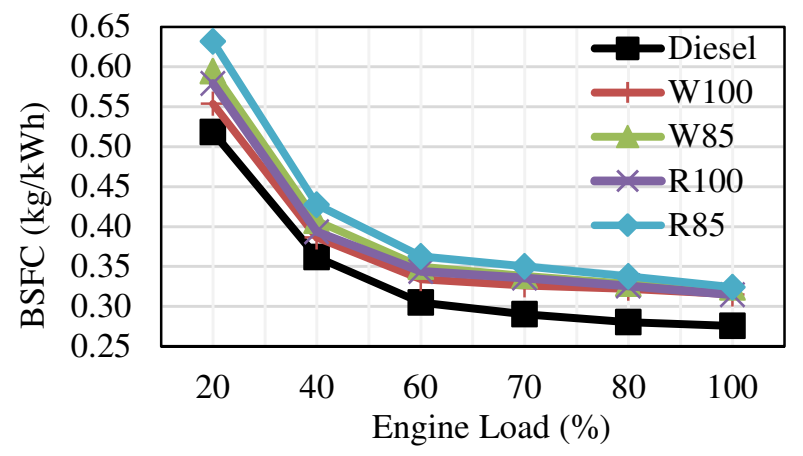

Fig. 5. BSFC of test fuels as a function of the engine loads.

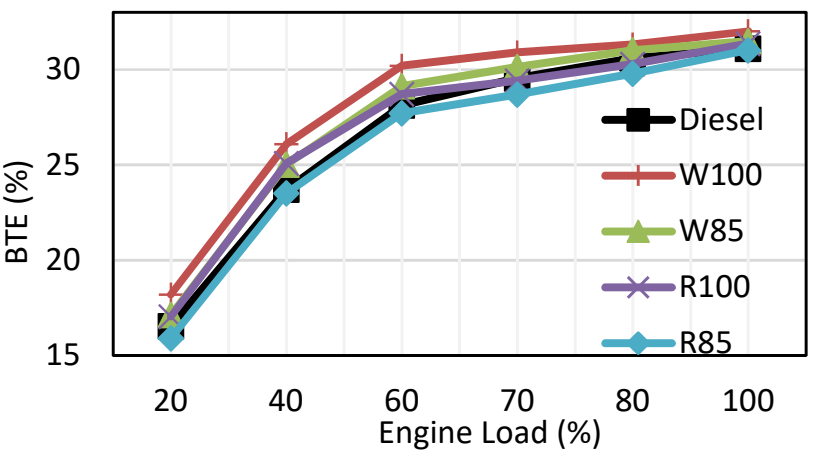

Fig. 6. BTE of test fuels as a function of engine loads.

\subsection{Combustion characteristics}

Combustion parameters data such as total heat release, heat release rate, in-cylinder pressure, combustion start and finish times, total combustion duration, fuel injection pressure and knock intensity were recorded and analysed. In-cylinder pressure and heat release data were presented (using 51 cycles) with respect to the crank angle position. Whereas, rest of the combustion parameters were illustrated with respect to the engine load, the arithmetic average of 51 indication cycles were used. Engine was stable will all fuels including biodieseladditive blends. Figure 7 represents in-cylinder pressure behaviour of the test fuels at low, mid-range, and high loads. At the lowest load (20\%), in-cylinder pressures of the neat biodiesels (W100 and R100) were quite similar to those obtained for fossil diesel. Whereas, the peak in-cylinder pressures at lowest load were found to be approximately 6\% higher for W85 and R85 fuels (Figure 7a). The higher values of the peak in-cylinder pressures were caused due to the increased volatility of the biodiesel blends. The results also indicated that as the engine load increases, the in-cylinder pressures of the neat biodiesels were also increased almost at a similar rate with the biodiesel blends. For example, at 60\% engine load, R100 and R85 fuels provided similar peak incylinder pressure; however, they are approximately 7.7\% higher than the corresponding value of fossil diesel (Figure 7b). Increased in-cylinder pressures observed for biodiesels and their blends proved that combustion was improved due to the presence of higher oxygen content in those fuels. At full load condition, all biofuels gave about $6 \%$ higher peak pressures than the corresponding value obtained for fossil diesel (Figure 7d). At full load, peak in-cylinder pressure of all biodiesels (and blends) was delayed by about $5{ }^{\circ} \mathrm{CA}$ when compared to fossil diesel (Figure 7d). This was caused due to the relatively higher ignition delays of the biodiesels and their blends than the corresponding value of fossil diesel. 


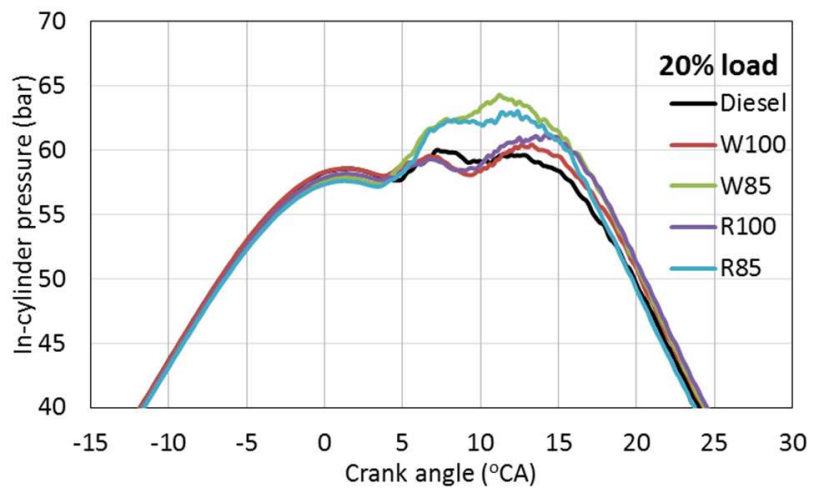

(a)

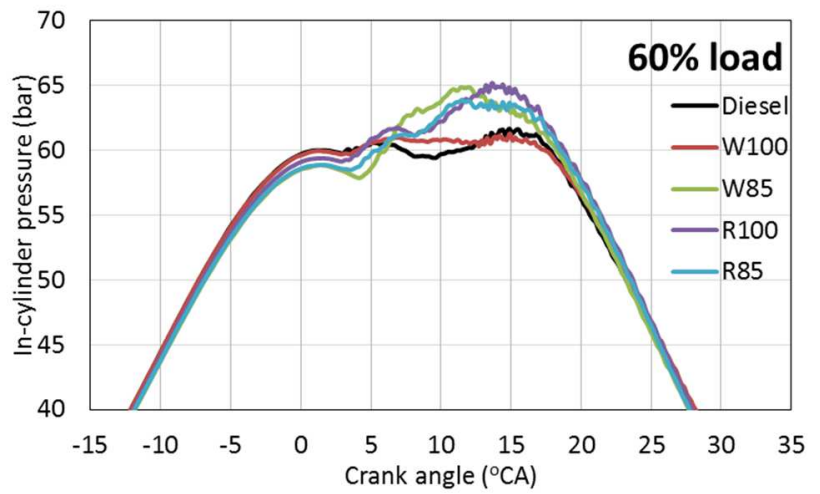

(b)

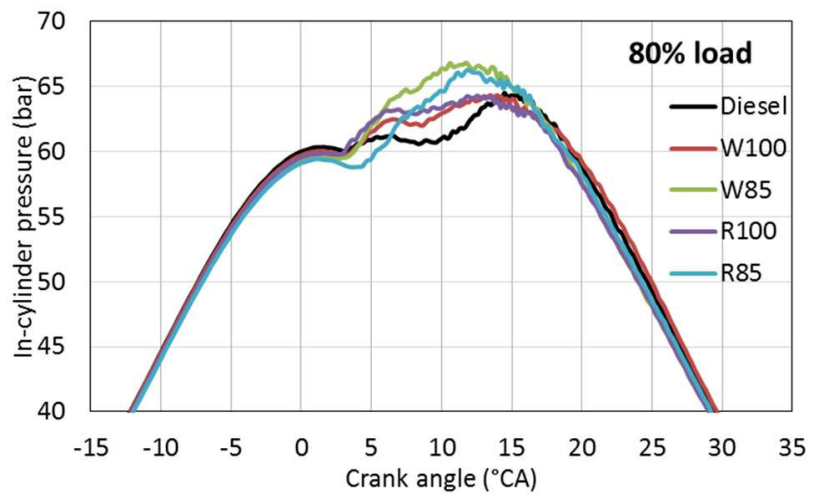

(c)

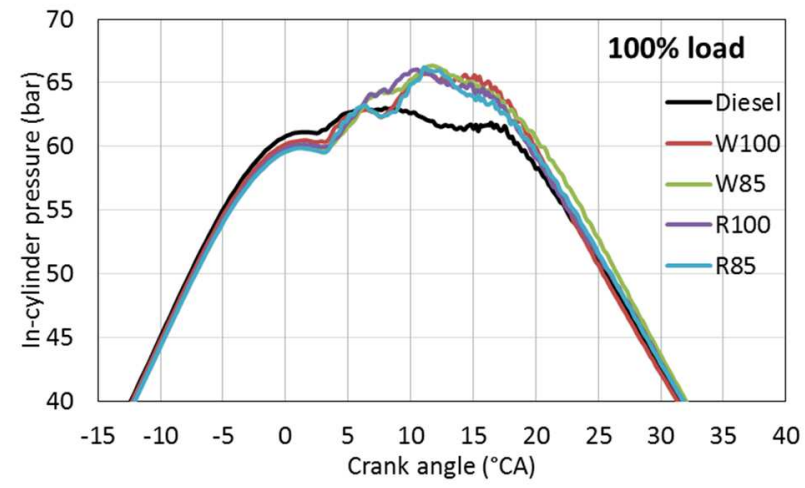

(d)

Fig. 7. In-cylinder pressure and crank angles at (a) $20 \%$ (b) $60 \%$ (c) $80 \%$ and (d) $100 \%$ loads. 
Start and end of combustion were analysed and presented in Figure 8. Combustion start angle was measured when $5 \%$ of the combustion took place and similarly combustion finish angle was recorded at $90 \%$ of the total combustion (Figure 8a and 8b). The differences between the finish and start angles were reported to identify the total combustion duration (Figure 8c). In most engine loads, start of combustion of biodiesel-additive blends were earlier than fossil diesel (Figure 8a). However, it was found that end of combustion for biodiesel-additive blends occurred earlier than fossil diesel and neat biodiesels (Figure 8b). These results agree with the similar studies (with different alcohol blends) found in the literature [24,49].

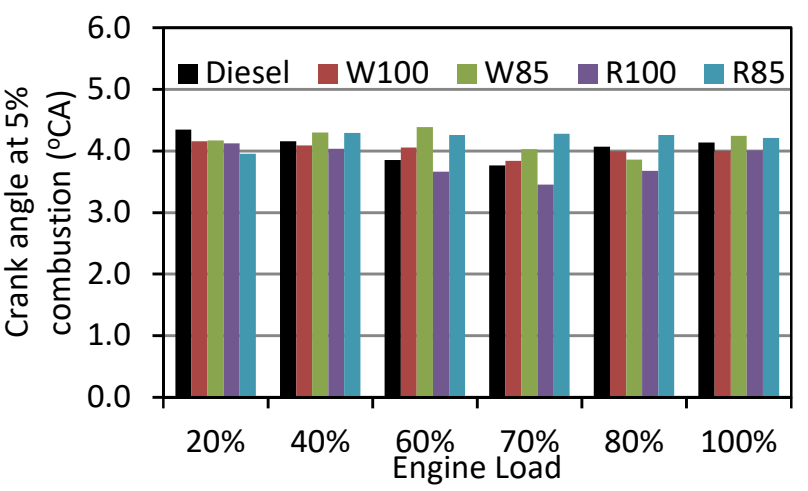

(a)

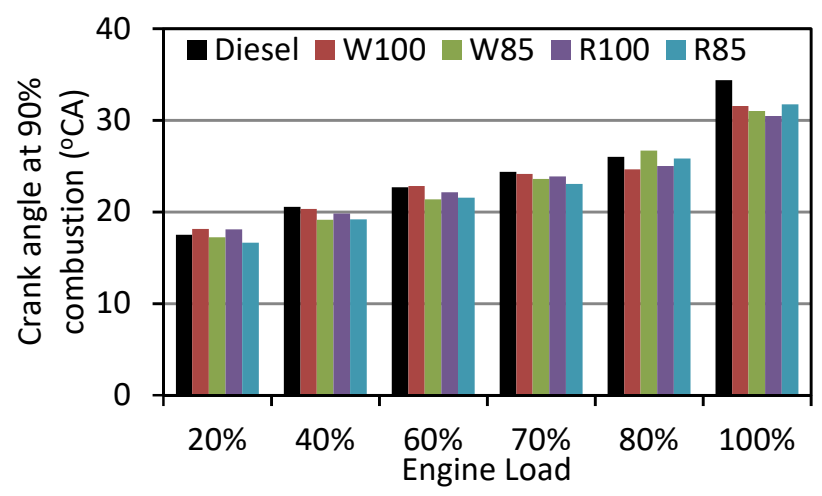

(b)

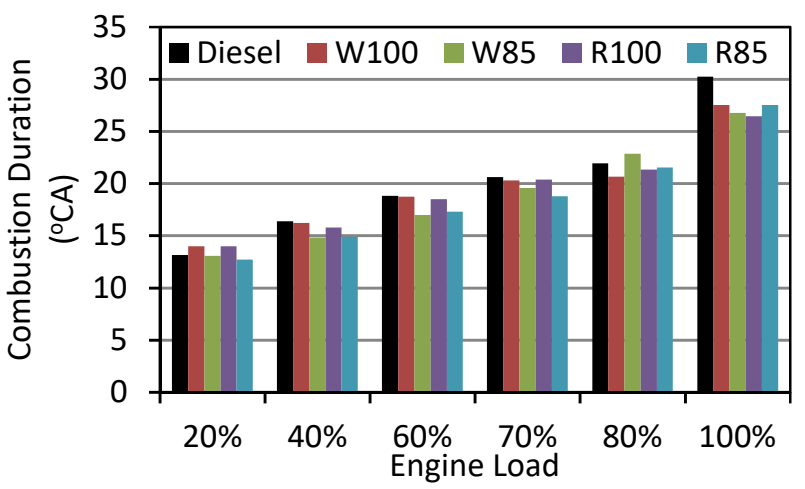

(c)

Fig. 8. Combustion characteristics: (a) start of combustion, (b) end of combustion, and (c) combustion duration.

Total combustion duration of the W85 fuel was approximately $0-4{ }^{0} \mathrm{CA}$ and $0-1{ }^{0} \mathrm{CA}$ lower than fossil diesel and W100 fuel respectively (except 80\% load) - Figure 8c. Similarly, combustion duration of the R85 was 
reported 1-2 ${ }^{\circ} \mathrm{CA}$ less than both diesel and R100 at low and mid-range loads. When compared to fossil diesel, maximum reductions in combustion duration were observed at the highest load by approximately $3{ }^{\circ} \mathrm{CA}, 4{ }^{\circ} \mathrm{CA}$, $4{ }^{\circ} \mathrm{CA}$ and $3{ }^{\circ} \mathrm{CA}$ for W100, W85, R100 and R85 respectively (Figure 8c). This analyses proved that once combustion starts, 2-butoxyethanol blends of biodiesels burn quicker than fossil diesel and neat biodiesels. Reduced viscosity and higher oxygen content in the biodiesel-additive blends might have caused this behaviour. Moreover, increased volatility and better dissociation of fuel molecules might have helped in rapid burning of the 2-butoxyethanol blends. Energy release data of all fuels are shown in Figure 9. W85 and R85 fuels were providing higher heat release especially during the early phases ie. between approximately $3{ }^{\circ}$ and $15^{\circ} \mathrm{CA}$ at all engine loads. For example, at the low (20\%) and medium (60\%) engine loads, heat release data of both W85 and R85 fuels at $10{ }^{\circ} \mathrm{CA}$ was about $17 \%$ (23 Joules) higher than the corresponding values of fossil diesel and neat biodiesels (Figure 9). The higher heat release of the biodiesel-additive blends (W85 and R85) can be attributed to their increased volatility and lower viscosity. On the other hand, it was found that at high load, due to the high combustion temperature, heat release of the blends and neat biodiesels were comparable (Figure 9d). Maximum heat release rates of the fuels were analysed for 51 cycles and the arithmetic mean is shown in Figure 10. Similar to heat release, no clear trend was observed for maximum heat release rates at low loads. However, it was seen that, after $60 \%$ engine load, the deviations in heat release rates between the biodiesels and their blends with additive were not significant. The first reason of this was believed to be relatively higher combustion temperature which eliminates the effect of high viscosities. Secondly, the higher enthalpy of vaporisation of 2butoxyethanol resulted in achieving better maximum heat release rates at higher combustion temperatures.

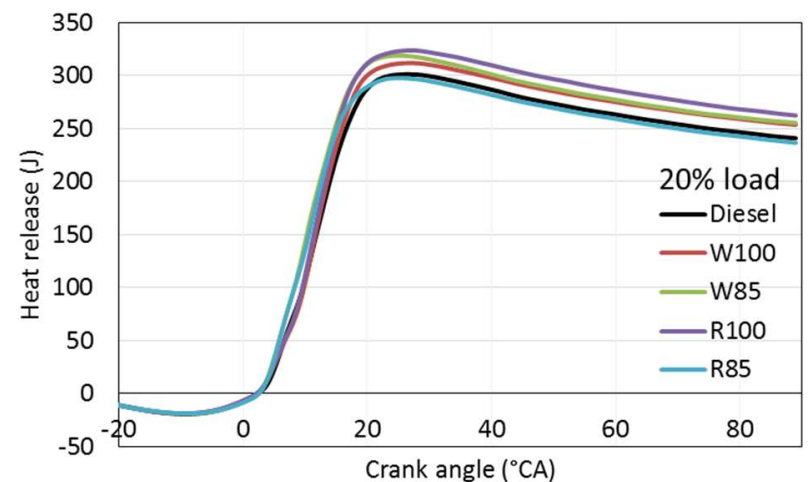

(a)

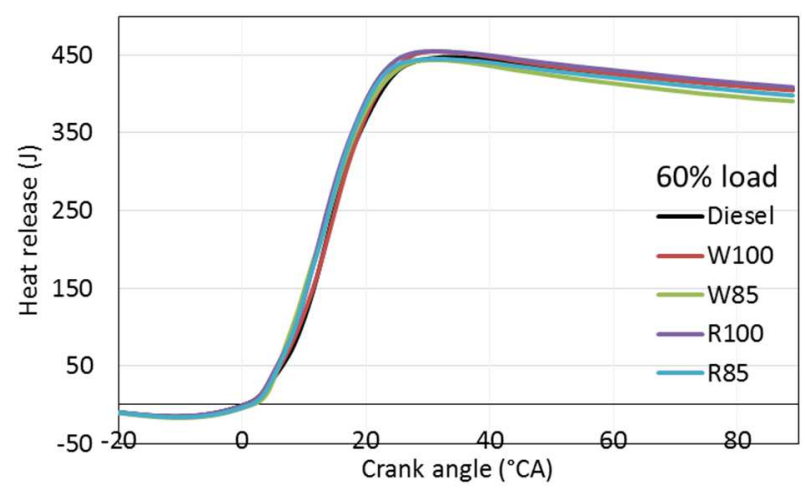

(b) 


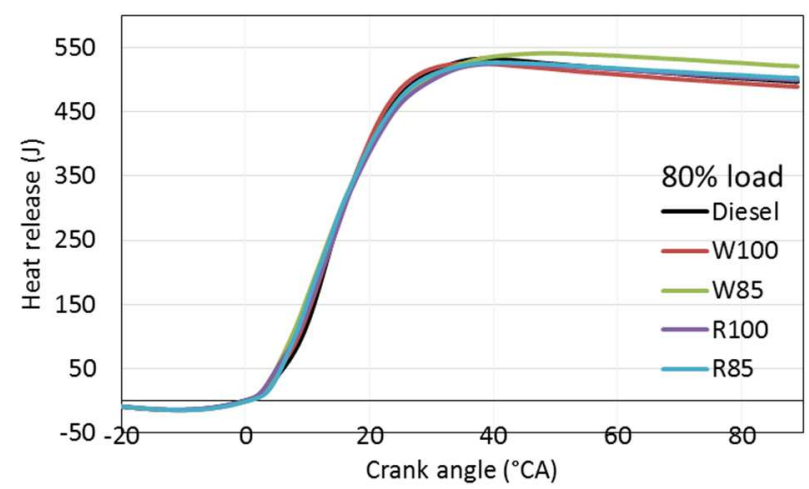

(c)

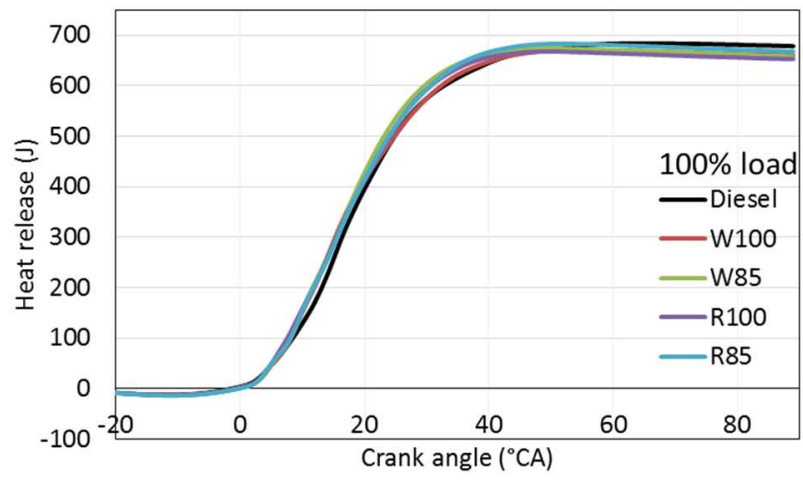

(d)

Fig. 9. Heat release of the test fuels at various loads: (a) at $20 \%$, (b) at $60 \%$, (c) at $80 \%$, and (d) at $100 \%$ loads.

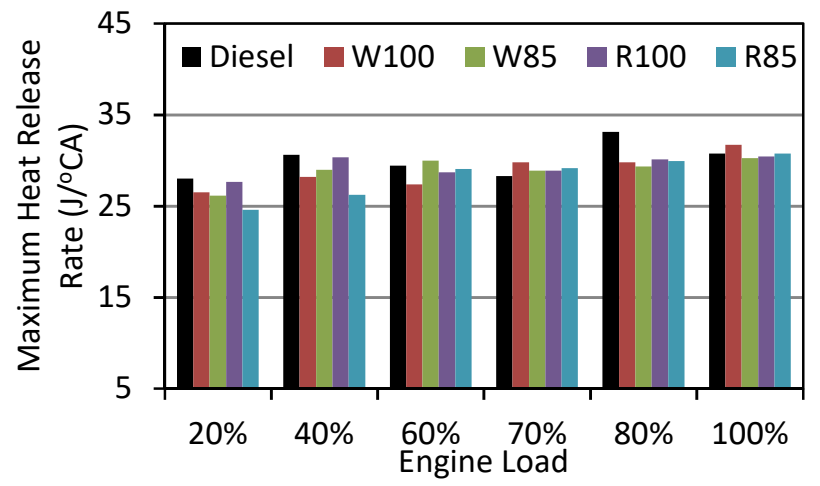

Fig. 10. Maximum heat release rates of the fuels at different engine loads.

\subsection{Exhaust gas emissions}

Figure 11 shows variation of $\mathrm{CO}_{2}$ gas emissions with engine loads. It was observed that $\mathrm{CO}_{2}$ gas emissions were increased with the increase in engine loads (Figure 11) as fuel consumption increases with the increase in engine load. Although, all test fuels exhibited comparable $\mathrm{CO}_{2}$ emissions, biodiesel blends were emitting slightly higher (approximately 1-2\%) $\mathrm{CO}_{2}$ than other fuels. This slight increased may be due to the enhanced combustion of the 2-butoxyethanol blends which turns more carbon atoms into carbon dioxide. Unlike $\mathrm{CO}_{2}$ emission, $\mathrm{O}_{2}$ emissions were linearly decreasing with the increasing engine load (Figure 12). The amount of air intake is constant, and as a result, the $\mathrm{O}_{2}$ gas emission decreases due to the increased reaction between the 
relatively higher amount of fuel molecules and the same amount of air (oxygen) molecules at the higher loads. Theoretically, biodiesels are likely to reduce the $\mathrm{HC}$ emission as the additional oxygen content provides more complete combustion [50]. Hence, biodiesel blends were expected to emit reduced HC emission as total oxygen content increases with addition of 2-butoxyethanol additive. Experimental results proved the theory as W85 and R85 emitted almost up to $100 \%$ reduced $\mathrm{HC}$ emissions than both their neat biodiesel versions and the fossil diesel (Figure 13). However, R85 provided uneven HC emission distribution (Figure 13), this could be due to the error in measurement and accuracy level of the gas analyser.

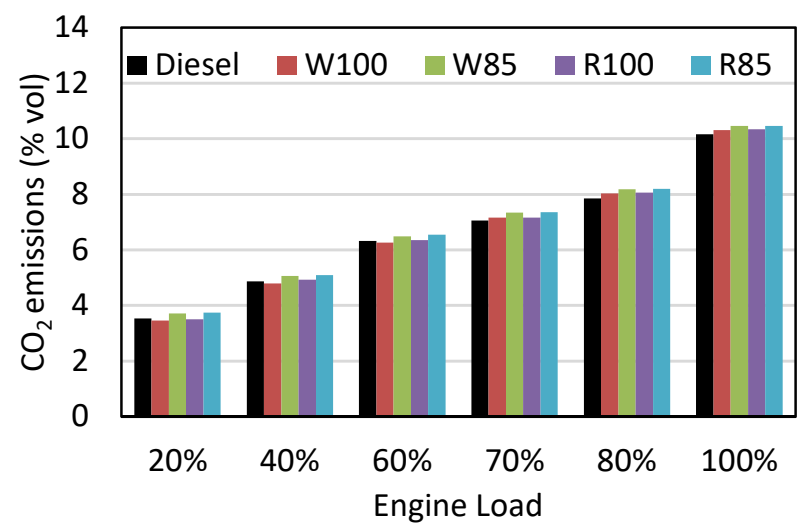

Fig. 11. $\mathrm{CO}_{2}$ emissions of the test fuels at different engine loads.

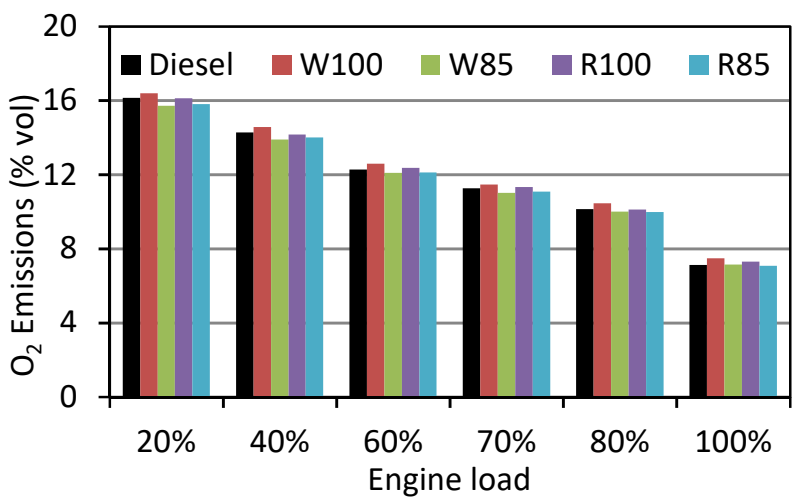

Fig. 12. $\mathrm{O}_{2}$ emissions of the test fuels at different engine loads.

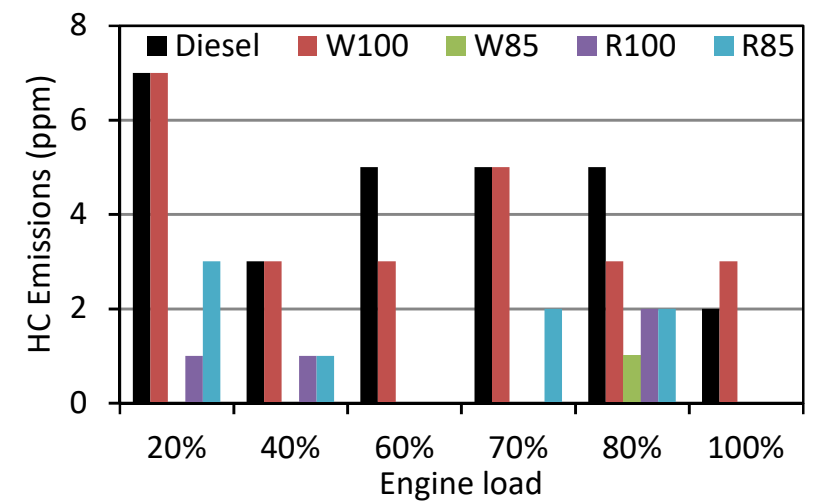

Fig. 13. HC emissions of the test fuels at different engine loads. 
Figure 14 provides the $\mathrm{CO}$ emissions of the test fuels at different loads. It can be clearly deemed that on average, addition of 2-butoxyethanol into WCO biodiesel decreased the CO emission by approximately $25 \%$. In contrast, 2-butoxyethanol additive increased the $\mathrm{CO}$ emission by around $12 \%$ when added to RO biodiesel. This result shows that type of biodiesel feedstock is important for 2-butoxyethanol blending. Furthermore, W85 emitted $10 \%$ less CO (on average) compared to fossil diesel. The reduction in CO emission was presumably due to relatively higher oxygen content (Table 6) and reduced viscosity of the WCO biodiesel which led to better combustion [51].

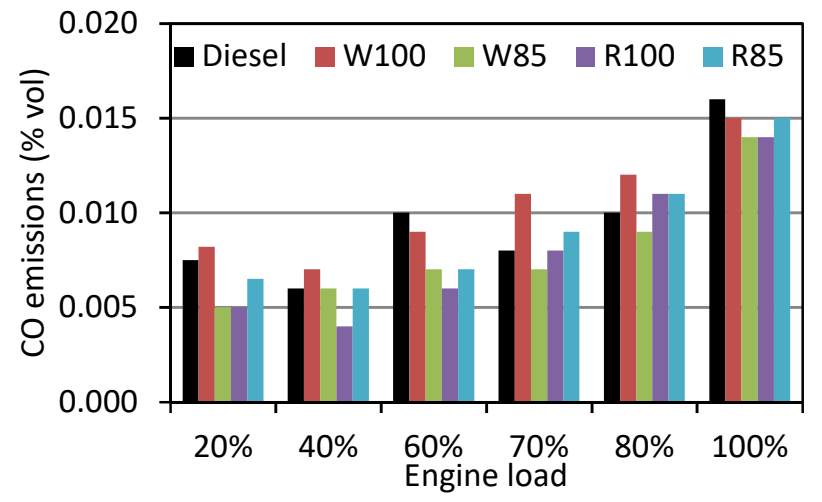

Fig. 14. CO emissions of the test fuels at different engine loads.

Emission of nitrogen oxide gas is shown in Figure 15. The 2-butoxyethanol blends exhibited different behaviours at low, medium and high loads. To illustrate, until the 40\% engine load, W 85 emitted around $15 \%$ higher NO emission than W100 fuel. Then at medium loads, NO emissions of W100 and W85 were comparable. At full load, W85 fuel gave about 5.4\% and 3.5\% lower NO emission than neat biodiesel and fossil diesel respectively. Figure 16 presents smoke opacity of the test fuels at various loads. It was clearly observed that smoke opacities of the biodiesels (and blends) were significantly reduced when the load on the engine was increased. Compared to fossil diesel, maximum reductions on smoke opacities were recorded at the highest engine load as 73\%,79\%, 66\% and 71\% for W100, W85, R100 and R85 fuels respectively. Reductions in smoke opacities were attributed to the extra oxygen content present in biodiesels (and blends) [52]. At full load, the smoke opacity values of the biodiesel-additive blends were approximately $5 \%$ lower than the corresponding values found for neat biodiesels.

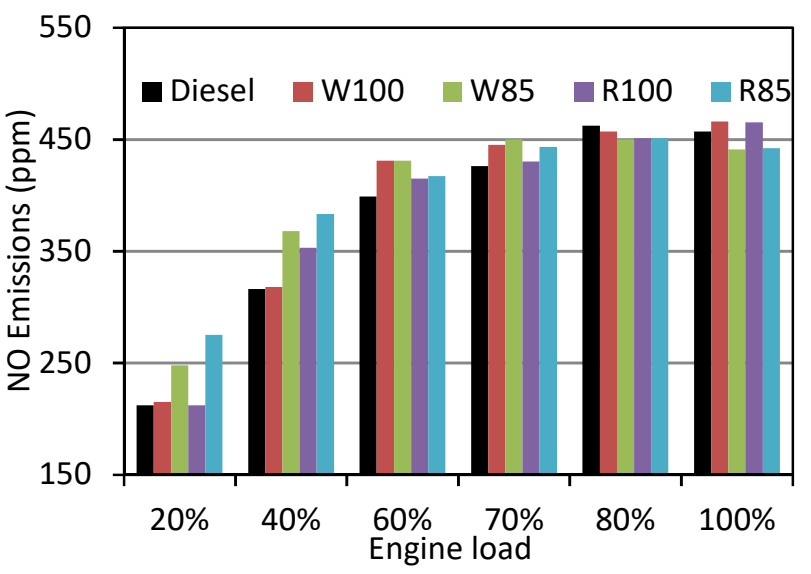

Fig. 15. NO emissions as a function of engine load. 


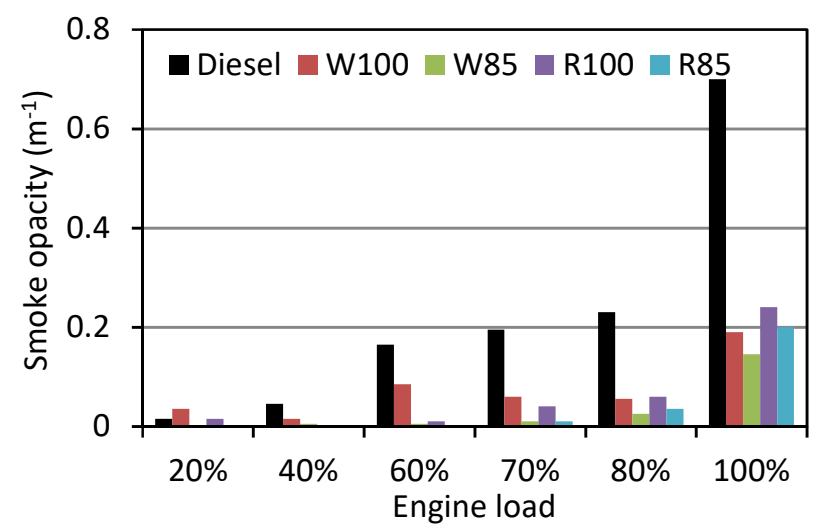

Fig. 16. Smoke opacity of the test fuels at different engine loads.

\subsection{Economic feasibility analysis}

A simple economic analysis was carried out to analyse the feasibility of using 2-butoxyethanol as biodiesel additive. Waste cooking oil was obtained from a restaurant in Birmingham, UK. Whereas, RO was bought from a commercial supplier. Table 7 shows list of materials with their quantity to prepare a litre of biodiesel and the biodiesel-additive blends. Note that, materials used for titration purposes such as isopropyl alcohol and indicator were not included in the analysis. In addition, it was assumed that the electrical power consumptions for heating and mechanical stirring were negligible. According to the data provided by the Department for Business, Energy \& Industrial Strategy [53], diesel price in the UK was 115.63 pence/litre (including tax) on 3 July 2017. Table 8 shows the total cost of fuel samples, W100 and W85 fuels were approximately 100 and 35 pence/litre cheaper than the commercial fossil diesel. In addition, the cost of R100 was found to be equal to that of fossil diesel. However, the cost of the R85 was around 55 pence/litre higher than the diesel due to its feedstock price (Table 7).

\section{Table 7}

Quantity and the price of materials used to produce 1 litre of test fuel.

\begin{tabular}{lccc}
\hline \multicolumn{1}{c}{ Substance } & $\begin{array}{c}\text { Quantity required to produce } \\
\text { 1 L biodiesel }\end{array}$ & $\begin{array}{c}\text { Quantity required to produce 1L } \\
85 \% \text { biodiesel-15\%alcohol blend }\end{array}$ & $\begin{array}{c}\text { Unit } \\
\text { Price }\end{array}$ \\
\hline WCO & $1 \mathrm{~L}$ & $0.85 \mathrm{~L}$ & 0 \\
RO & $1 \mathrm{~L}$ & $0.85 \mathrm{~L}$ & $1 £ / \mathrm{L}$ \\
Methanol & $0.2 \mathrm{~L}$ & $0.17 \mathrm{~L}$ & $0.7 £ / \mathrm{L}$ \\
KOH for WCO & $10.5 \mathrm{~g}$ & $8.9 \mathrm{~g}$ & $1.5 £ / \mathrm{kg}$ \\
KOH for RO & $8.2 \mathrm{~g}$ & $7.0 \mathrm{~g}$ & $1.5 £ / \mathrm{kg}$ \\
2-Butoxyethanol & 0 & $0.15 \mathrm{~L}$ & $4.8 £ / \mathrm{L}$ \\
\hline
\end{tabular}

Table 8

Total costs of one litre fuel samples.

\begin{tabular}{|c|c|c|c|c|}
\hline & $\begin{array}{c}\text { Cost of W100 } \\
£ / L\end{array}$ & $\begin{array}{c}\text { Cost of W85 } \\
£ / L\end{array}$ & $\begin{array}{c}\text { Cost of R100 } \\
\mathfrak{f} / \mathrm{L}\end{array}$ & $\begin{array}{c}\text { Cost of R85 } \\
£ / L\end{array}$ \\
\hline Feedstock (WCO or RO) & 0 & 0 & 1 & 0.85 \\
\hline Methanol & 0.14 & 0.12 & 0.14 & 0.12 \\
\hline $\mathrm{KOH}$ & 0.02 & 0.01 & 0.01 & 0.01 \\
\hline 2-Butoxyethanol & 0 & 0.72 & 0 & 0.72 \\
\hline Total cost & 0.16 & 0.85 & 1.15 & 1.70 \\
\hline
\end{tabular}




\section{Conclusion}

The 2-butoxyethanol additive (15\% by volume) was added separately to waste cooking oil biodiesel and rapeseed oil biodiesel. The physical and chemical properties of these blends were measured and compared to the corresponding properties of the neat biodiesels and fossil diesel fuels. The fuels were tested in a multi-cylinder compression ignition engine. Engine performance, combustion and emission characteristics of the 2butoxyethanol-WCO biodiesel (W85) and the 2-butoxyethanol-RO biodiesel (R85) blends were compared to both neat biodiesels (W100 \& R100) and fossil diesel. No instability or abnormalities were observed in the incylinder pressure diagrams; i.e. the engine ran smoothly when 2-butoxyethanol-biodiesel blend was used in the engine. Overall, 2-butoxyethanol additive gave improved emissions when used with both biodiesels. However, considering engine performance, emission reduction and cost parameters, it was found out that 2-butoxyethanolWCO biodiesel blend was superior to the 2-butoxyethanol-RO biodiesel blend. The major findings of the study are summarised below:

(i) BSFC of the WCO biodiesel was increased by approximately $4.3 \%$ when blended with the 2butoxyethanol additive. The BSFC of the R85 was observed as 5.2\% and $18.8 \%$ greater than R100 and diesel respectively. The additive decreased BTE of the W100 fuel by about 2.6\%. Nevertheless, BTE of the W85 fuel was still $3.7 \%$ higher than the diesel.

(ii) Both W85 and R85 fuels released around 17\% higher energy at the early stages of the combustion. At $80 \%$ engine load, the maximum heat release of the W85 was approximately $6.5 \%$ and $4.8 \%$ greater than the W100 and diesel respectively. Total combustion duration of the W85 was $4{ }^{\circ} \mathrm{CA}$ shorter than the fossil diesel fuel on average.

(iv) The NO emission of the W100 fuel was comparable with the diesel at the maximum engine load. W85 fuel reduced the NO emission by $5.4 \%$ and $3.5 \%$ when compared to the corresponding values of the $\mathrm{W} 100$ and neat fossil diesel. Both W85 and R85 fuels emitted almost up to $100 \%$ reduced HC emissions than neat biodiesels and the fossil diesel. Compared to diesel, W85 fuel gave significant reductions in CO, HC and smoke emissions by $36 \%, 100 \%$ and $79 \%$ respectively.

(v) Basic economic analysis showed that a litre of W85 fuel was about 30 pence cheaper than the commercial fossil diesel.

This study concludes that the 2-butoxyethanol could be used as an effective and safe biodiesel additive. Current study proved that 2-butoxyethanol additive enhanced the fuel properties, and gave significant improvement in engine performance and emission when the additive was added to WCO biodiesel. However, it should be noted that depending on the source of biodiesel feedstock, 2-butoxyethanol-biodiesel blends can be more expensive than fossil diesel. Further techno-economic analyses using other biodiesels need to be carried out and recommended as a future work. Investigation on the effects of fossil diesel addition (as a third component) into the 2-butoxyethanol-biodiesel blend is another R \& D topic.

\section{Acknowledgments}

This study was supported by: (i) PhD scholarship, School of Engineering and Applied Science, Aston University, UK (ii) UKIERI funded project 'Waste to Engine - Low Temperature Combustion of Sustainable Green Fuels'.

\section{References}

[1] Z.D. Ristovski, B. Miljevic, N.C. Surawski, L. Morawska, K.M. Fong, F. Goh, I.A. Yang, Respiratory health effects of diesel particulate matter, Respirology. 17 (2012) 201-212. https://doi.org/10.1111/j.1440-1843.2011.02109.x.

[2] J.O. Anderson, J.G. Thundiyil, A. Stolbach, Clearing the air: a review of the effects of particulate matter air pollution on human health, J. Med. Toxicol. 8 (2012) 166-175. https://doi.org/10.1007/s13181-0110203-1. 
[3] L.C. Chen, M. Lippmann, Effects of metals within ambient air particulate matter (PM) on human health, Inhal. Toxicol. 21 (2009) 1-31. https://doi.org/10.1080/08958370802105405.

[4] J.-H. Tsai, S.J. Chen, K.L. Huang, W.Y. Lin, W.J. Lee, C.C. Lin, L.T. Hsieh, J.Y. Chiu, W.C. Kuo, Emissions from a generator fueled by blends of diesel, biodiesel, acetone, and isopropyl alcohol: analyses of emitted PM, particulate carbon, and PAHs, Sci. Total Environ. 466 (2014) 195-202. https://doi.org/10.1016/j.scitotenv.2013.07.025.

[5] C.C. Lin, S.J. Chen, K.L. Huang, W.I. Hwang, G.P. Chang Chien, W.Y. Lin, Characteristics of metals in nano/ultrafine/fine/coarse particles collected beside a heavily trafficked road, Environ. Sci. Technol. 39 (2005) 8113-8122. https://doi.org/10.1021/es048182a.

[6] C.C. Lin, S.J. Chen, K.L. Huang, W.J. Lee, W.Y. Lin, J.H. Tsai, H.C. Chaung, PAHs, PAH-induced carcinogenic potency, and particle-extract-induced cytotoxicity of traffic-related nano/ultrafine particles, Environ. Sci. Technol. 42 (2008) 4229-4235. https://doi.org/10.1021/es048182a 10.1021/es703107w.

[7] S.C. Chuang, S.J. Chen, K.L. Huang, E.M.Y. Wu, G.P. Chang Chien, L.C. Wang, Gas/particle partitioning of dioxins in exhaust gases from automobiles, Aerosol Air Qual. Research. 10 (2010) 489496. https://doi.org/10.1021/es048182a 10.4209/aaqr.2010.04.0028.

[8] Y. He, D.B. Brown, S. Lu, M.J. Paratore, J. Li, Opportunities and challenges for blended 2-way SCR/DPF aftertreatment technologies, SAE Tech. Pap. 2009-01-0274. 1 (2009) 14. https://doi.org/10.4271/2009-01-0274.

[9] J.M. López, F. Jiménez, F. Aparicio, N. Flores, On-road emissions from urban buses with SCR+ Urea and EGR+ DPF systems using diesel and biodiesel, Transp. Res. Part D Transp. Environ. 14 (2009) 1-5. https://doi.org/10.1016/j.trd.2008.07.004.

[10] Y. Sogawa, H. Hattori, N. Yanagisawa, M. Hosoya, T. Shoji, Y. Iwakiri, T. Yamashita, T. Ikeda, S. Tanaka, K. Takahashi, others, Nano particle emission evaluation of state of the art diesel aftertreatment technologies (DPF, urea-SCR and DOC), gasoline combustion systems (Lean Burn/Stoichiometric DISI and MPI) and fuel qualities effects (EtOH, ETBE, FAME, Aromatics and Distillation), SAE Trans. 116 (2007) 1013-1023. doi:www.jstor.org/stable/44650937.

[11] A.E. Atabani, A.S. Silitonga, I.A. Badruddin, T.M.I. Mahlia, H.H. Masjuki, S. Mekhilef, A comprehensive review on biodiesel as an alternative energy resource and its characteristics, Renew. Sustain. Energy Rev. 16 (2012) 2070-2093. doi:10.1016/j.rser.2012.01.003.

[12] A.K. Hossain, P.A. Davies, Performance, emission and combustion characteristics of an indirect injection (IDI) multi-cylinder compression ignition (CI) engine operating on neat jatropha and karanj oils preheated by jacket water, Biomass and Bioenergy. 46 (2012) 332-342. https://doi.org/10.1016/j.biombioe.2012.08.007.

[13] K. Masera, A.K. Hossain, Production , Characterisation and assessment of biomixture fuels for compression ignition engine application, Int. J. Mech. Mechatronics Eng. 11 (2017) 1857-1863. doi:scholar.waset.org/1307-6892/10008317.

[14] A.K. Hossain, P.A. Davies, Pyrolysis liquids and gases as alternative fuels in internal combustion engines - A review, Renew. Sustain. Energy Rev. 21 (2013) 165-189. doi:10.1016/j.rser.2012.12.031.

[15] Y. Yang, T. Fu, W. Bao, G.H. Xie, Life cycle analysis of greenhouse gas and PM2.5 emissions from restaurant waste oil used for biodiesel production in china, Bioenergy Res. 10 (2017) 199-207. doi:10.1007/s12155-016-9792-5.

[16] M. Mofijur, A.E. Atabani, H.H. Masjuki, M.A. Kalam, B.M. Masum, A study on the effects of promising edible and non-edible biodiesel feedstocks on engine performance and emissions production: A comparative evaluation, Renew. Sustain. Energy Rev. (2013). doi:10.1016/j.rser.2013.03.009.

[17] S.M. Palash, M.A. Kalam, H.H. Masjuki, B.M. Masum, I.M. Rizwanul Fattah, M. Mofijur, Impacts of biodiesel combustion on NOxemissions and their reduction approaches, Renew. Sustain. Energy Rev. 23 (2013) 473-490. doi:10.1016/j.rser.2013.03.003.

[18] S.K. Hoekman, C. Robbins, Review of the effects of biodiesel on NOx emissions, Fuel Process. Technol. (2012). doi:10.1016/j.fuproc.2011.12.036. 
[19] P. Verma, M.P. Sharma, G. Dwivedi, Evaluation and enhancement of cold flow properties of palm oil and its biodiesel, Energy Reports. 2 (2016) 8-13. doi:10.1016/j.egyr.2015.12.001.

[20] A. Datta, B.K. Mandal, Engine performance, combustion and emission characteristics of a compression ignition engine operating on different biodiesel-alcohol blends, Energy. 125 (2017) 470-483. https://doi.org/10.1016/j.energy.2017.02.110.

[21] P.V. Bhale, N. V. Deshpande, S.B. Thombre, Improving the low temperature properties of biodiesel fuel, Renew. Energy. 34 (2009) 794-800. doi:10.1016/j.renene.2008.04.037.

[22] L.N. Silva, C.C. Cardoso, V.M.D. Pasa, Production of cold-flow quality biodiesel from high-acidity onedible oils-esterification and transesterification of macauba (acrocomia aculeata) oil using various alcohols, Bioenergy Res. 9 (2016) 864-873. doi:10.1007/s12155-016-9740-4.

[23] K. Varatharajan, M. Cheralathan, Influence of fuel properties and composition on NO x emissions from biodiesel powered diesel engines: A review, Renew. Sustain. Energy Rev. 16 (6) (2012) 3702-3710.

[24] L. Zhu, C.S. Cheung, W.G. Zhang, Z. Huang, Emissions characteristics of a diesel engine operating on biodiesel and biodiesel blended with ethanol and methanol, Sci. Total Environ. 408 (2010) 914-921. https://doi.org/10.1016/j.scitotenv.2009.10.078.

[25] M.H.M. Yasin, T. Yusaf, R. Mamat, A.F. Yusop, Characterization of a diesel engine operating with a small proportion of methanol as a fuel additive in biodiesel blend, Appl. Energy. 114 (2014) 865-873. doi.10.1016/j.apenergy.2013.06.012.

[26] N. Yilmaz, Performance and emission characteristics of a diesel engine fuelled with biodiesel--ethanol and biodiesel--methanol blends at elevated air temperatures, Fuel. 94 (2012) 440-443. https://doi.org/10.1016/j.fuel.2011.11.015.

[27] N. Vedaraman, S. Puhan, G. Nagarajan, K.C. Velappan, Preparation of palm oil biodiesel and effect of various additives on NOx emission reduction in B20: An experimental study, Int. J. Green Energy. 8 (2011) 383-397. https://doi.org/10.1080/15435075.2011.557847.

[28] N. Yilmaz, Comparative analysis of biodiesel--ethanol--diesel and biodiesel--methanol--diesel blends in a diesel engine, Energy. 40 (2012) 210-213. https://doi.org/10.1016/j.energy.2012.01.079.

[29] E. Tosun, A.C. Yilmaz, M. Ozcanli, K. Aydin, Determination of effects of various alcohol additions into peanut methyl ester on performance and emission characteristics of a compression ignition engine, Fuel. 126 (2014) 38-43. https://doi.org/10.1016/j.fuel.2014.02.037.

[30] S. Sarıkoç, S. Ünalan, İ. Örs, Experimental study of hydrogen addition on waste cooking oil biodieseldiesel-butanol fuel blends in a di diesel engine, Bioenergy Res. 12 (2019) 443-456. doi:10.1007/s12155-019-09980-x.

[31] S. Saravanan, R. Kaliyanasunder, B. Rajesh Kumar, G. Lakshmi Narayana Rao, Effect of design parameters on performance and emissions of a CI engine operated with diesel-biodiesel- higher alcohol blends, Renew. Energy. 148 (2020) 425-436. doi:10.1016/j.renene.2019.10.049.

[32] T. Zhang, J. Eismark, K. Munch, I. Denbratt, Effects of a wave-shaped piston bowl geometry on the performance of heavy duty Diesel engines fueled with alcohols and biodiesel blends, Renew. Energy. 148 (2020) 512-522. doi:10.1016/j.renene.2019.10.057.

[33] Radheshyam, K. Santhosh, G.N. Kumar, Effect of 1-pentanol addition and EGR on the combustion, performance and emission characteristic of a CRDI diesel engine, Renew. Energy. 145 (2020) 925-936. doi:10.1016/j.renene.2019.06.043.

[34] J.D. Rogers, T.L. Burke, S.G. Osborn, J.N. Ryan, A framework for identifying organic compounds of concern in hydraulic fracturing fluids based on their mobility and persistence in groundwater, Environ. Sci. Technol. Lett. 2 (2015) 158-164. doi:10.1021/acs.estlett.5b00090.

[35] Robert E. Sievers and Thomas J. Wenzel, Liquid hydrocarbon-soluble rare earth chelates prepared from the novelligand 2,2,7-trimethyl-3,5-octanedione and fuels Containing Same, 1981. doi:United States Patent Appl. No.: 17,459.

[36] Methyl-Alcohol, National center for biotechnology information, PubChem Open Chem. Database. 
(2018). https://pubchem.ncbi.nlm.nih.gov/compound/887\#section=Top (accessed July 16, 2018).

[37] Ethanol, National center for biotechnology information, PubChem Open Chem. Database. (2018). https://pubchem.ncbi.nlm.nih.gov/compound/702\#section=Top (accessed July 16, 2018).

[38] Butyl-Alcohol, National center for biotechnology information, PubChem Open Chem. Database. (2018). https://pubchem.ncbi.nlm.nih.gov/compound/263\#section=Top (accessed July 16, 2018).

[39] 2-Butoxyethanol, National center for biotechnology information, PubChem Open Chem. Database. (2018). https://pubchem.ncbi.nlm.nih.gov/compound/2-Butoxyethanol\#section=Top (accessed July 16, 2018).

[40] Fisher Scientific, 2-Butoxyethanol, 99\%, ACROS OrganicsTM, (2018) 1. https://www.fishersci.com/shop/products/2-butoxyethanol-99-acros-organics-5/p-3735784 (accessed June 26, 2018).

[41] Esso, Esso synergy diesels, (2019). https://www.esso.co.uk/diesel (accessed March 5, 2019).

[42] British Standard Institution, Bs En 14214:2008+a1:2009 Automotive fuels — Fatty acid methyl esters (FAME) for diesel engines - Requirements and test methods, Br. Stand. Inst. (2010) 22. doi:ISBN 978 0580707810 .

[43] D. Tong, C. Hu, K. Jiang, Y. Li, Cetane number prediction of biodiesel from the composition of the fatty acid methyl esters, J. Am. Oil Chem. Soc. 88 (2011) 415-423. doi:10.1007/s11746-010-1672-0.

[44] L.F. Ramírez-Verduzco, J.E. Rodríguez-Rodríguez, A.D.R. Jaramillo-Jacob, Predicting cetane number, kinematic viscosity, density and higher heating value of biodiesel from its fatty acid methyl ester composition, Fuel. 91 (2012) 102-111. doi:10.1016/j.fuel.2011.06.070.

[45] A. Schönborn, N. Ladommatos, J. Williams, R. Allan, J. Rogerson, The influence of molecular structure of fatty acid monoalkyl esters on diesel combustion, Combust. Flame. 156 (2009) 1396-1412. doi:10.1016/j.combustflame.2009.03.011.

[46] M.D. Redel Macías, S. Pinzi, D.E. Leiva Candia, A.J. Cubero Atienza, M.P. Dorado, Influence of fatty acid unsaturation degree over exhaust and noise emissions through biodiesel combustion, Fuel. 109 (2013) 248-255. doi:10.1016/j.fuel.2012.12.019.

[47] G. Vellguth, Performance of vegetable oils and their monoesters as fuels for diesel engines, SAE Trans. 92 (1983) 1098-1107. doi:www.jstor.org/stable/44647674.

[48] G.M. Tashtoush, M.I. Al Widyan, M.M. Al Jarrah, Experimental study on evaluation and optimization of conversion of waste animal fat into biodiesel, Energy Convers. Manag. 45 (2004) 2697-2711. https://doi.org/10.1016/j.enconman.2003.12.009.

[49] K. Anand, R.P. Sharma, P.S. Mehta, Experimental investigations on combustion, performance and emissions characteristics of neat karanji biodiesel and its methanol blend in a diesel engine, Biomass and Bioenergy. 35 (2011) 533-541. https://doi.org/10.1016/j.biombioe.2010.10.005.

[50] L. Li, J. Wang, Z. Wang, J. Xiao, Combustion and emission characteristics of diesel engine fueled with diesel/biodiesel/pentanol fuel blends, Fuel. 156 (2015) 211-218. https://doi.org/10.1016/j.fuel.2015.04.048.

[51] H.K. Imdadul, H.H. Masjuki, M.A. Kalam, N.W.M. Zulkifli, M. Kamruzzaman, M.M. Shahin, M.M. Rashed, Evaluation of oxygenated n-butanol-biodiesel blends along with ethyl hexyl nitrate as cetane improver on diesel engine attributes, J. Clean. Prod. 141 (2017) 928-939. https://doi.org/10.1016/j.jclepro.2016.09.140.

[52] P. Baskar, A. Senthilkumar, Effects of oxygen enriched combustion on pollution and performance characteristics of a diesel engine, Eng. Sci. Technol. an Int. J. 19 (2016) 438-443. doi:10.1016/j.jestch.2015.08.011.

[53] E.\& I.S. Department for Business, Statistical data set weekly road fuel prices (CSV), Wkly. road fuel Prices. (2017). https://www.gov.uk/government/uploads/system/uploads/attachment_data/file/624619/CSV.csv/preview (accessed July 4, 2017). 